\title{
Review Article \\ Effect of GH/IGF-1 on Bone Metabolism and Osteoporsosis
}

\author{
Vittorio Locatelli ${ }^{1}$ and Vittorio E. Bianchi ${ }^{2}$ \\ ${ }^{1}$ Department of Health Sciences, School of Medicine, University of Milano Bicocca, Milan, Italy \\ ${ }^{2}$ Endocrinology Department, Area Vasta N. 1, Cagli, Italy
}

Correspondence should be addressed to Vittorio E. Bianchi; dott.vbianchi@gmail.com

Received 13 March 2014; Revised 17 June 2014; Accepted 18 June 2014; Published 23 July 2014

Academic Editor: Robert D. Murray

Copyright (C) 2014 V. Locatelli and V. E. Bianchi. This is an open access article distributed under the Creative Commons Attribution License, which permits unrestricted use, distribution, and reproduction in any medium, provided the original work is properly cited.

Background. Growth hormone (GH) and insulin-like growth factor (IGF-1) are fundamental in skeletal growth during puberty and bone health throughout life. GH increases tissue formation by acting directly and indirectly on target cells; IGF-1 is a critical mediator of bone growth. Clinical studies reporting the use of GH and IGF-1 in osteoporosis and fracture healing are outlined. Methods. A Pubmed search revealed 39 clinical studies reporting the effects of GH and IGF-1 administration on bone metabolism in osteopenic and osteoporotic human subjects and on bone healing in operated patients with normal GH secretion. Eighteen clinical studies considered the effect with GH treatment, fourteen studies reported the clinical effects with IGF-1 administration, and seven related to the GH/IGF-1 effect on bone healing. Results. Both GH and IGF-1 administration significantly increased bone resorption and bone formation in the most studies. GH/IGF-1 administration in patients with hip or tibial fractures resulted in increased bone healing, rapid clinical improvements. Some conflicting results were evidenced. Conclusions. GH and IGF-1 therapy has a significant anabolic effect. GH administration for the treatment of osteoporosis and bone fractures may greatly improve clinical outcome. GH interacts with sex steroids in the anabolic process. GH resistance process is considered.

\section{Introduction}

GH and IGF-1 are fundamental in achieving a normal longitudinal bone growth and mass during the postnatal period and, in association with sex steroids, play a major role in bone growth and development [1]. GH deficiency in childhood decreases bone mineral density (BMD), while GH treatment increases bone growth and strength [2]; IGF-1 is considered essential for longitudinal bone growth, skeletal maturation, and bone mass acquisition not only during growth but also in the maintenance of bone in adult life [3]. A positive correlation between serum IGF-1 level and BMD has been documented in women but not in men [4], in very old women [5], by others in men but not in women [6], and in healthy men [7]. Lower serum IGF-1 levels in women are reported to be correlated with the prevalence of fractures [8] and are strongly associated with an increased risk of osteoporotic fractures independently by BMD [9]. Recently, Ohlsson et al. [10] demonstrated that low serum IGF-1 levels were associated with an increased risk of fractures of about $40 \%$ and serum IGF-1 level could be clinically useful for assessing the risk of vertebral fractures [11]. Osteoporosis in postmenopausal women is due to estrogen (E) deficiency and having a high rate of bone remodeling with bone resorption exceeding bone formation [12]. The E deficiency is critical to the pathogenesis of osteoporosis in men and in women and the frequency of GH secretion is decreased in the amplitude with sex hormone reduction [13]. In young men the most significant hormonal determinants of the BMD of the hip and of the cortical thickness of the femoral neck are $17 \beta$ estradiol and IGF-1 while in aged men (over 60 years) the BMD was not correlated with IGF-1 at any site but only at $17 \beta$-estradiol [14]. It has been documented extensively that $\mathrm{E}$ is one of the factors regulating the expression of IGF1 in maintaining skeletal integrity $[15,16]$. The IGF-1 plays a central role in cellular growth, differentiation, survival, and cell cycle progression [17] and IGF-1 level is necessary for the proper acquisition of peak bone mass; furthermore GH protects against ovariectomy-induced bone loss [18]. Despite the evident anabolic effect of GH/IGF-1 on bone some conflicting clinical studies are evident. The aim of the present review is to evaluate the clinical studies published in 
the literature on the effect of GH and IGF-1 on bone metabolism in human subjects affected by severe osteoporosis and bone healing after surgery in non-GH deficient subjects.

\section{The GH/IGF-1 Axis}

$\mathrm{GH}$ is a polypeptide hormone secreted by the anterior pituitary gland. The synthesis of GH is under the control of central and peripheral signals. The primary site of GH action is the liver where it stimulates IGF-1 production [19]. $\mathrm{GH}$ has a direct effect on various tissues including liver, kidney, and muscle [20-22]. GH also acts on the central nervous system [23] and bone [24]. The action of GH is mediated by the binding of $\mathrm{GH}$ to the transmembrane $\mathrm{GH}$ receptor (GHR) which is present on the surface of most cells. The GHR is a major effector of human growth action and of the functional physiologic variants. GHRs in humans are expressed in the liver, adipose tissue, heart, kidney, intestine, lung, pancreas, cartilage, and skeletal muscle where they induce the synthesis of IGF-1 [25]. The GH has two different dependent and independent mechanisms of action, one directly through the GHR and the other inducing IGF1 secretion. Circulating IGF-1 is mostly synthetized in the liver, but IGF-1 is expressed in all tissues, suggesting that autocrine/paracrine effects of local IGF-1 may be a major mechanism controlling tissue growth [26]. IGF-1 null mice exhibit severe growth retardation and mostly die soon after birth [27] although the autocrine/paracrine IGF-I, but not liver-derived IGF-I, is the major determinant of postnatal body growth [28] and the extrahepatic tissue levels of IGFI are regulated by GH. IGF-1 circulates in a ternary form bound with the IGF binding protein IGFBP- 3 and the acid labile subunit (ALS). There are six IGF-BPs and the IGFBP3 represent the predominant binding protein for IGF-1 [29]. The IGF-1 regulatory system consists of IGF-1, IGF-II, and IGF-receptors and six binding proteins including IGFBP1-6 [30]. Many central and peripheral factors regulate GH secretion [31]. IGFBP-3 is the principal binding protein in circulation, has similar affinity to both IGFs, binds $75 \%$ of IGFs in plasma [32], and regulates the free active IGF-1 concentration [33].

\section{GH Intracellular Signaling}

The GHR system utilizes the Janus kinase (JAK) signal transducer and activator of transcription (STAT) signal transduction pathway [34]. The activated GHR is associated with JAK2, a tyrosine kinase that once activated by GH, phosphorylates STATs- $1,-3,-5 a$, and $5 b$ tyrosine and Stat $5 b$ is the predominant target of GH. The STAT proteins translocate to the nucleus where they bind to the specific DNA sequences and activate gene transcription. In addition, recent studies have indicated that suppression of cytokine signaling (SOCS) proteins also controls the GH signaling pathway [35]. These proteins play an important role in growth and skeletal development as well as in inflammation. In particular, the SOCS2 protein has a role in downregulating GH/IGF1 signaling and has a functional role in the chondrocytes of the growth plate dynamics [36]. Chronic inflammation is associated with altered growth and skeletal development, and the SOCS proteins may also have an important role to play in mediating these effects.

\section{Hormone Measurements}

The valid determination of GH and IGF-1 in biological fluids is fundamental for a correct clinical evaluation [37]. Human GH is a heterogeneous protein hormone consisting of several isoforms and represents one important reason for the disparity among $\mathrm{GH}$ assay results from different laboratories [38]. Recently Frystyk et al. [39] discussed the current state of the art of IGF-I immunoassays and presented the analytical problems with IGF-I measurements. The pronounced binding of IGF-I to the high-affinity IGFbinding proteins (IGFBPs) constitutes a notorious source of error. For GH measurement generally is used Beckman Access Ultrasensitive human GH, a chemiluminescent assay with $96 \%$ specificity with $22 \mathrm{kDa}$ human GH molecule and $4 \%$ cross reactivity with GH variant [40]. The serum IGF-1 is measured by the Immulite 2000 assay by Siemens Health care Diagnostic. The intra-assay for the serum IGF-1 ranges from 2.3 to $3.9 \%$ and the intra-assay $\mathrm{CV}$ range ranges from 3.7 to $8.1 \%$ [41]. For the detection of free hormones the mass spectrometry in the clinical laboratory has helped to develop proposed reference measurement procedures [42].

\section{The Effect of GH/IGF-1 on Bone}

The somatomedin hypothesis proposed by Salmon and Daughaday in 1957 [43] was that GH stimulates growth at the epiphysis by systemically derived liver IGF-1, but this has been challenged based on questionable direct effects of GH on chondrocytes in vivo and in vitro [44] and an alternative dual effector theory of GH action has been proposed [45].

In vitro studies using cultured chondrocytes have evidenced that GH stimulated the formation of colony of young precondrocytes directly while IGF-1 stimulated cells at later stage of maturation [46] and this preferential effect of GH on precondrocytes in vivo was also supported by another study of Ohlsson et al. [47]. GH is the major determinant of stimulation of progenitor cells and interacts with progenitor cells in adipose tissue and cartilage and IGF-1 stimulate a subsequent clonal expansion [48, 49]. GH and IGF-1 stimulate the preadipocytes at different stages of development and a direct action exerted on osteoblasts has been demonstrated [24]. The activity of IGF-1 on osteoblastic cells is increased by the presence of GH and IGFBP-3 [50]. IGF-1 is not able to substitute for GH in promoting this differentiation, but its mitogenic action selectively promotes cell multiplication in young differentiated clones.

GH and IGF-1 stimulate tissue growth with integrated functions. In fact IGF-1 is quite effective in stimulating growth in patients affected by $\mathrm{GH}$ insensitivity syndrome [5155] but this effect becomes less effective due to lack of GHinduced IGFBP-3 stimulation of precondrocytes. Both GH 
and IGF-1 are considered potential anabolic agents because they play physiological roles in bone mass acquisition and maintenance [56]. The administration of GH and IGF-1 has the capacity to stimulate the longitudinal bone growth in animals and humans by acting both directly [57] and indirectly increasing local production of IGF-1 stimulating IGF-1-gene [51, 52, 58-61]. GH and IGF-1 have independent and different functions [62] and when the two compounds are given together they exert a synergistic effect [63].

5.1. In Vivo Studies. GH and IGF-1 have independent and different functions: the administration of $\mathrm{GH}$ to animals treated with maximal doses of IGF-1 stimulated growth further [62]. The effect was seen both in the tibia and in the femur whereas no significant effect was seen in the vertebrae. The lack of GH secretion and consequently low level of IGF-1 display osteopenia and reduced cortical bone, but normal trabecular bone in transgenic mice carrying a mutation of the GHRH receptor has been shown. Bone turnover was significantly reduced in $\mathrm{GHR}(-/-)$ mice, indicating $\mathrm{GH}$ involvement in the high bone-turnover level during growth. IGF-I treatment almost completely rescued all effects of the $\mathrm{GHR}(-/-)$ on both bone growth and remodeling, supporting a direct effect on both osteoblasts and chondrocytes [64]. IGF-1 plays an essential role in the development of the growing skeleton by influencing both longitudinal and transverse bone accrual and in the maintenance of bone mass during late adulthood and aging [65]. The administration of IGF-1 to GHdeficient animals and humans showed that both hormones have the capacity to stimulate longitudinal bone growth [53]. IGF-1-deficient mice exhibited skeletal malformations, a delayed mineralization, reduced chondrocyte proliferation, and increased chondrocyte apoptosis [66]. In mice carrying liver-specific IGF-1 deletion, which display a reduction in serum IGF-1, a decreased cortical bone is demonstrated [67]. The systemic IGF-1 contributes to cortical bone integrity, while the bone trabecular integrity is sustained by the locally produced skeletal IGF-1 [68]. A threshold concentration of circulating IGF-1 is necessary for normal bone growth and IGF-1, IGFBP-3, and ALS play a prominent role in the pathophysiology of osteoporosis [69].

5.2. GH and Bone Resorption In Vitro. Unlike bone formation, GH seems to have a more profound independent stimulatory effect on bone resorption. Proinflammatory cytokines such as TNF- $\alpha$, IL-1beta, and IL- 6 can promote osteoclastogenesis, and GH and IGF-1 can stimulate production of these cytokines in osteoblasts $[70,71]$. Diminished GH receptor mRNA concentrations in response to IL-1 beta and TNFalpha indicate that low IGF-1 levels during severe illness, despite high circulating $\mathrm{GH}$ levels, may at least partially be a consequence of suppression of hepatic $\mathrm{GH}$ receptor synthesis by IL-1 beta and TNF-alpha [72, 73]. GH increases IL-6 produced by human osteoblast-like cells. This in vitro evidence suggests, for the first time, a mechanistic paradigm by which $\mathrm{GH}$ modulates bone resorption [73]. The levels of GH, IGF-1, and some IGF binding proteins (IGFBPs) decrease in the elderly [5] and in osteoporotic subjects [74, 75] and low circulating levels of IGF-1 in elderly women are associated with greater femoral bone loss [76] suggesting a consistent effect of the anabolic IGF components on overall bone formation rate. Interestingly, the age-dependent attenuation of GH, IGF-I, and IGFBP-3 levels among healthy men, however, is not correlated with the reduction of BMD $[4,77]$ suggesting other hormonal interactions.

5.3. Role of IGFBP-3. The IGFBP-3 functions are complex and well summarized in a review by Yamada and Lee [78]. Current research demonstrating IGFBP-3's IGF independent roles in suppressing tumor formation and carcinoma cell growth has used autocrine/paracrine models [79, 80]. IGFBP-3 is able to modulate cell growth, the interplay between IGFBP3 systemic and local regulation. The IGF-I/IGFBP-3 ratio, are positively related with PINP (N-terminal propeptide of human procollagen type I, a bone formation marker) and CTX (carboxy-terminal collagen crosslinks, a bone resorption marker) as a bone resorption marker in healthy adult men younger than 55 years and premenopausal women. In older subjects the found positive as well as negative relations with BTMs have to be further investigated [81].

\section{Sex Steroids and Bone}

$\mathrm{E}$ and androgens (A) exert potent influences on the size and shape of the skeleton during growth and contribute to skeletal homeostasis during adulthood [82]. Sex steroid hormones act on their target cells by binding to members of the nuclear hormone receptor superfamily: $\mathrm{E}$ binds to estrogen receptor $\mathrm{ER} \alpha$ or $\mathrm{ER} \beta$, and $\mathrm{A}$ bind to the androgen receptor (AR) [83]. Mouse models with cell-specific deletion of the estrogen receptors $\mathrm{ER} \alpha, \mathrm{ER} \beta$, and the $\mathrm{AR}$ have provided novel insights into the function and signalling of these receptors on bone health and disease well evidenced by Monalagas et al. [84]. Human bone cells obtained from men and women have similar concentrations of AR and ER suggesting that both sex steroids have an important role in bone mass maintenance [85]. The A action on bone is more complex in males, because it not only activates the AR but also acts on two different estrogen receptors: receptor$\alpha(\mathrm{ER} \alpha)$ or receptor- $\beta(\mathrm{ER} \beta)$ following aromatization, the conversion of $\mathrm{T}$ to $\mathrm{E}$ by aromatase [86]. The AR function is essential for normal bone growth and remodeling in male mice [87]. In mice completely lacking $A R$, a reduction in trabecular and cortical bone mass was observed [88]. A stimulate radial bone expansion in males and an optimal radial cortical bone expansion appears to require both $\mathrm{AR}$ and $\mathrm{ER} \alpha$ signaling. The effects of $\mathrm{E} / \mathrm{ER} \alpha$ are mediated, at least in part, via interactions with the IGF system [83, 84, 89]. Ovariectomy and orchidectomy cause a dramatic increase in osteoblast and osteocytes apoptosis in mice. In addition, estrogens and androgens suppress osteoblast and osteocyte apoptosis induced by a variety of proapoptotic stimuli in vitro [90]. The effects of sex steroids on antiapoptosis are mediated via the classical ERs (ER $\alpha$ or ER $\beta)$ or the AR. The distribution of these bone receptors on bone cells are at similar level in men and women [91] and this can explain the paradox why 
E restores bone mass in males with aromatase deficiency [92], while nonaromatizable androgens can protect the female skeleton against the adverse effects of estrogen deficiency [93]. An increase in osteocyte apoptosis following loss of estrogen in rats as well as in humans has been observed [94] and the accumulation of apoptotic osteocytes could increase bone fragility even before significant loss of bone mass because of the impaired detection of microdamage and repair of substandard bone. Activation of ER $\alpha$ has no effect on cortical and trabecular bone mass, which represents $80 \%$ of skeleton mass, indicating that the mechanism by which estrogen protects against the resorption of trabecular bone is on the osteoclasts [95]. The ER $\alpha$ is required for the osteogenic response to mechanical loading in a ligandindependent manner. Loading increases cortical bone area as a result of increased periosteal bone formation in both estrogen-sufficient and estrogen-deficient mice [96]. The AR has an important role in the homeostasis of the male skeleton with idiopathic hypogonadotropic hypogonadism or complete androgen insensitivity syndrome because of a lossof-function mutation in AR having low bone mass [97]. The deletion of $\mathrm{AR}$ in male mice results in high bone turnover with a decreased trabecular and cortical bone volume [98]. $\mathrm{AR}$ is responsible for the preservation of trabecular bone in male mice [99].

\section{Interaction of GH/IGF-1 with Estrogen}

$\mathrm{E}$ is the major hormonal regulator of bone metabolism in both women and men [100] and is important for maintaining bone formation at the cellular level. E deficiency is highly correlated with bone resorption and has a major role in regulating bone resorption in men [101]. Falahati-Nini studied the relative contributions of testosterone versus estrogen in regulating bone metabolism in men. They observed that $\mathrm{E}$ accounted for $70 \%$ or more of the total effect of sex steroids on bone resorption in older men, whereas testosterone could account for no more than $30 \%$ of the effect, but androgen plays a fundamental role. The administration of $\mathrm{GH}$ in ovariectomized (OVX) rats increases cortical bone mass by inducing subperiosteal bone formation [102] resulting in an increase in bone volume, mineralizing surface, and osteoid surface. The effect of IGF-1 on the osteoblast progenitor cells is impaired in OVX mice [103]. These studies, using ovariectomized rats, indicate that GH alone stimulates bone growth and mineralization in the absence of estrogen alone. The association of GH plus E treatment in OVX rats resulted in an additive increase in the cancellous bone mass, which can be attributed to the suppressive effect of $\mathrm{E}$ on bone resorption and the anabolic effect of $\mathrm{GH}$ on bone formation [104]. GH and E reduced cancellous osteopenia, through different mechanisms. GH reduced the decrease in trabecular thickness, whereas $\mathrm{E}$ reduced the decrease in trabecular number and the increase in trabecular separation [105]. These results emphasize that not only bone loss is evident with $\mathrm{E}$ deficiency, but it is preventable by $\mathrm{E}$ administration. However, the administration of $\mathrm{E}$ is not able to restore bone loss [106]. High doses of $\mathrm{E}$ have a lowering effect on the serum level of IGF-1, and, in the proximal tibial metaphysis, E greatly suppresses the longitudinal growth rate and a lowered resorption of the cancellous bone mass [107]. The administration of $\mathrm{E}$, but not $\mathrm{T}$, significantly reduce circulating free IGF-I availability $[108,109]$ and the treatment with estrogen fails to restore the attributes of GH/IGF-1 axis in postmenopausal women. Conversely, low doses have a stimulatory effect on GH secretion in both sexes [110]. So that the association between bone mass and GH/IGF-1 level in women and not in men is due due to E inhibition on IGF1 secretion, while free $\mathrm{T}$ induces an elevation. These effects may contribute to the gender differences observed in the GHIGF-1 axis in healthy adults as well as in the responsiveness of hypopituitary patients to GH substitution [111].

\section{Interaction of GH/IGF-1 with Androgens}

A, including testosterone and its derivatives, are needed for skeletal growth and bone accrual during puberty and the effects are well evidenced in other reviews [112]. A stimulate radial bone expansion in males and an optimal radial cortical bone expansion appears to require both AR and ER $\alpha$ signaling, with the effects of estrogen/ER $\alpha$ being mediated, at least in part, via interactions with the IGF system [89]. A stimulate human and murine osteoblastic cell proliferation in vitro, and induce expression of the osteoblast-line differentiation marker ALP [113]. Oxandrolone stimulates production of osteoblast differentiation affecting the osteoblast AR and stimulating type I collagen synthesis [114]. The major role for AR activation in normal development is the trabecular bone and periosteal bone growth in male mice. Moreover, optimal stimulation of periosteal growth is only obtained in the presence of both AR and ER activation [115]. When GH and $\mathrm{T}$ were combined, the cortical bone area, periosteal bone formation rate (BFR), and femoral BMD were all significantly higher than that of the ORX and even higher than in the intact control rats. The treatment of androgen-deficient aged male rats by the administration of GH in association with $\mathrm{T}$ may have an independent effect in preventing osteopenia. The significant effect of GH+T may be attributed to the prevention of intracortical porosis and an increase in periosteal bone formation and cortical bone mass [116]. In humans, $\mathrm{T}$ indirectly stimulates IGF-1 secretion after aromatization into estrogen [117], while there is no evidence of fluctuation in GH responsiveness in hypogonadal men replaced with $\mathrm{T}$ or DHT alone [118]. Furthermore, aromatase inhibitors, that block the E formation from T, lower serum IGF-1 levels [119]. The predominating effect of androgens on IGF-I production can be explained by the tissue conversion of $\mathrm{T}$ to $\mathrm{E}$. Longterm androgen deficiency results in a decrease in the calcium content of both tibia and lumbar vertebrae. In ORX old male rats the cancellous bone volume in the proximal tibial metaphysis was reduced by $50 \%$ four months after orchidectomy. At the same time, cortical bone was lost, the femoral cortical thickness was reduced by $12 \%$, and cortical density tended to be lower. T, Dihydrotestosterone (DHT), E, or Nandrolone treatment completely prevented this decrease in cortical thickness and density. $\mathrm{T}$ and Nandrolone were also able to 
prevent the cancellous bone loss [120]. The administration of aromatizable and nonaromatizable androgens in association with $\mathrm{GH}$ therapy could be greatly effective to increase bone formation rate and mass. $\mathrm{E}$ is a potent inhibitor of bone resorption, whereas testosterone plays a synergistic role with $\mathrm{GH}$ in bone development and mass and the larger cortical bone size in males compared with females [115]. In pre- and postmenopausal women, the relative importance of $\mathrm{A}$ for bone health is increased [121]. In hypopituitary women A levels are low and free testosterone correlates with IGF-I. Discontinuation of $\mathrm{E}$ replacement in these patients induces elevations in IGF-I as well as free testosterone, and Delta IGF-I correlated positively with Deltafree testosterone. These effects may contribute to the gender differences observed in the GH-IGF-1 axis in healthy adults as well as in the responsiveness of hypopituitary patients to $\mathrm{GH}$ substitution [111]; a certain threshold level of testosterone is necessary to permit IGF-I stimulation. Administration of testosterone increases serum IGF-I levels in normal [122] and hypopituitary men $[123,124]$ and intact AR function is required for the suppressive effects of androgens on the osteoclastogenesis supporting activity of osteoblasts, but not osteoclasts [98, 125].

\section{Effect of GH/IGF-1 on Osteoblasts and Osteoclasts}

Bone turnover is the result of a balance between bone resorption and formation. The resorption process starts with recruitment of osteoclasts followed by the activity of osteoblasts by removing old bone and replacing it with a young matrix. Osteoblastic cells (osteoprogenitor cells) originate from a group of skeletal stem cells with osteogenic differentiation potential, referred to as skeletal mesenchymal stem cells (MSC). MSC reach bone surfaces from the circulation through vascular channels in association with bone remodeling sites [126]. Once they have arrived at the bone surface, osteoblastic cells produce bone matrix that becomes mineralized. The old osteoblasts die by apoptosis or become embedded in bone matrix as osteocytes. Osteoblasts and chondrocytes have receptors for $\mathrm{GH}$ and the administration of $\mathrm{GH}$ at physiological doses exerts a direct action on osteoblasts, stimulating cell proliferation and differentiation $[24,127]$. There is a normal osteoblastic and osteoclastic response to $\mathrm{GH}$ also in osteopenic postmenopausal women [128]. IGF-1 reduces osteoblast apoptosis and promotes osteoblastogenesis by stabilizing $\beta$-catenin, enhancing Wntdependent activity [129]. The Wnt (Wingless and INT1) family of signaling proteins influences most aspects of embryonic development and postembryonic tissue homeostasis [130]. Cellular responses to these proteins are often categorized based on their utilization of $\beta$-catenin, activity of the Wnt/ $\beta$-catenin ("canonical") pathway maintains transcriptional programs that enable stem cells to remain multipotent [131]. Osteoblasts exhibit complex Wnt-induced effects and Wnt is essential for osteoblastogenesis. For details see the review [132]. Also E and androgen have important effects on osteoblast life and function. E has been shown to inhibit osteoblast apoptosis and increases osteoblast lifespan [90]. Various studies have demonstrated that osteoblasts are directly stimulated by androgen $[113,133]$. DHT (an androgen not convertible in estradiol) stimulates in vitro mineralization by a different mechanism from that of $1,25(\mathrm{OH}) \mathrm{D} 3$ and TGF$\beta$ and also increases androgen receptors. Less clear is the function of IGF-1 on osteoclasts. Osteoclasts express IGF-1 receptors and IGF-1 has direct effects on their function [134]. In vitro, IGF-1 induces RANK-L (receptor activator of nuclear factor $\kappa \mathrm{B}$ ) synthesis and, as a consequence, osteoclastogenesis [135]. The induction of RANK-L by IGF-1 may explain the stimulatory effects of IGF-1 on bone resorption, whereas the induction of osteoprotegerin by GH may temper these effects [136].

9.1. IGF-1 Production by Osteoblasts. IGF-1 is produced locally by osteoblasts under control not only by $\mathrm{GH}$, but also by other factors. Bone IGF-1 activity can be regulated at multiple levels [137]. It is well known that, in Ob cell models, both parathyroid hormone (PTH) and prostaglandin 2 (PGE2) can upregulate IGF-1 mRNA levels and that cAMP serves as the intracellular second signal [138]. Transient treatment stimulates collagen synthesis and the stimulatory effect is mediated by local production of IGF-I [139, 140]. The intermittent PTH treatment enhances osteoblasts differentiation through an IGF-I dependent mechanism and continuous PTH treatment enhances osteoclastogenesis through reciprocal which increases in RANKL and decreases in osteoprogerin [141]. The diverse effects on osteoblasts differentiation depending on the exposure time in vitro mediated through different signal transduction systems [142]. With aging there is an impaired osteoblastic function with reduced bone formation [143]. The role of GH/IGF-1/IGFBP signaling in age-related bone loss is very important: they promote osteoblastic cell proliferation and differentiation $[127,144]$ and the effects on osteoblasts and bone formation [145].

\section{Mechanostat and Aging}

There is inevitable age-related decline in bone mass that reflects a compromised signal transduction pathway that attenuates the ability of the skeleton to respond to osteogenic stimuli [146]. The physical stimuli are potent osteogenic signals in the young adult skeleton but are hardly evidenced in older bone tissue. The bone mass decline can be slowed or reversed by several therapeutic strategies: first, the effects of exercise and nutrition on the mechanostat model are fundamental [147] and represent the basic environmental factors known to affect muscle and bone development. Nutrition deficiencies have the most profound effect on mechanostat, and dietary protein is essential for bone health [148]. Mechanical forces are necessary to deform bone and stimulate bone regeneration and the trabecular tissue responds to diverse bone stressing exercises [149], although this is not consistent in all studies [150, 151]. Nutrition in association with hormonal factors works synergistically with exercise with respect to bone formation [152]. Aging processes could compromise signal transduction pathways 
reducing the tissue response to mechanical stimuli so that hormonal supplementation could be necessary.

\section{GH and IGF-1 in Osteoporosis}

The levels of GH, IGF-1, and some IGF binding proteins (IGF-BPs) decrease in the elderly [5] and in osteoporotic subjects [74, 75] and low circulating levels of IGF-1 in elderly women are associated with greater femoral bone loss [76] suggesting a consistent effect of the anabolic IGF components on overall bone formation rate. Serum IGF-I decreased with increasing age in both men and women and was higher in young women compared with young men in both cohorts, while the opposite was found in the highest age group $[5,6,153]$. Interestingly, the age-dependent attenuation of GH, IGF-I, and IGFBP-3 levels among healthy men, however, is not correlated with the reduction of BMD [77] suggesting that androgens interact with bone metabolism differently. In elderly men, BMD was not correlated with the IGF-I concentration [4]. In women with postmenopausal osteoporosis, serum IGF-I and II did not differ from the concentrations in normal women of similar age and did not correlate with BMD. There was no evidence that impaired synthesis of IGF-I and II contributes to the accelerated loss of trabecular bone and vertebral compression fractures [154]. The potential use of GH or IGF-1 as therapy for age-related bone loss is, however, controversial given their stimulatory effect on bone resorption, which may compromise their positive effect on bone formation. The complex mechanism of the effect of GH and IGF-1 on bone metabolism is evidenced in various clinical conditions that determine osteoporosis such as glucocorticoid induced osteoporosis, acromegaly, GHD patients, and senile osteoporosis.

States of GH resistance, such those observed in Laron dwarf patients, are characterized by mutations in the GHR resulting in a decreased serum and tissue IGF-1 levels. The IGF-1 replacement therapy in such patients increases growth velocity but does not normalize growth. In the GH-resistant mice (GHRKO-HIT mice) $[155,156]$, serum IGF-1 levels were restored via transgenic expression of Igf-1 and normalization of serum IGF-1 improved body adiposity and restored glucose tolerance but was insufficient to support normal skeletal growth, resulting in an osteopenic skeletal phenotype. The inability of serum IGF-1 to restore skeletal integrity in the total absence of GHR showed that GH-mediated effects on the skeleton are independent of serum or tissue IGF-1. These findings showed that IGF-I replacement therapy in patients with Laron syndrome does not achieve full skeletal growth [156].

11.1. Glucocorticoid Induced Osteoporosis. Glucocorticoid treatment causes osteoporosis and growth retardation in humans. Chronic glucocorticoid treatment induces a redistribution of spontaneous PTH secretory dynamics by reducing the amount released in tonic fashion and increasing the amount released as pulses [157]. Manolagas and Weinstein [158] found that in rodents as well as in humans increased apoptosis of osteoblast and osteocytes is a key pathogenetic mechanism of the adverse effects of glucocorticoid excess on bone. GH and IGF-I, but not GH alone, markedly counteracts diminished bone and body collagen synthesis caused by glucocorticoids, whereas connective tissue resorption is enhanced during treatment with $\mathrm{GH}$ alone or in combination with IGF-I [159].

11.2. Acromegaly. Acromegaly is caused by a pituitary tumor that secretes $\mathrm{GH}$ and the disease is characterized by elevated plasma levels of GH and IGF-1 [160] and their effects on bone mass and strength are not yet clearly defined. In acromegaly, GH and IGF-1 excess increases bone turnover and remodeling [161]. The serum concentration of osteocalcin is positively correlated with GH and IGF-1 levels [162]. The most studies reported an increase in BMD at the femoral neck, gender-independent [163-166]. Other studies showed a normal BMD [167] despite hypogonadism [168]. The normal BMD at lumbar spine was found in various studies $[163,164$, 166-170]. Zgliczynski et al. [171] found a smaller increase in bone resorption and greater increase in BMD in women with acromegaly than in men. Vestergaard and Mosekilde [172] found that fracture risk was significantly decreased in patients with acromegaly compared to controls due to the anabolic effect of GH on bone. The anabolic effect of GH on trabecular and cortical bone remained demonstrable after remission of acromegaly; the mean BMD remained normal both at lumbar spine and femoral neck but not at cortical sites in the long term [173]. In contrast, the bone histomorphometry by iliac crest bone biopsies demonstrated a significant increase in bone turnover with a decrease in cortical and trabecular bone mass $[174,175]$. The first observation that acromegaly could be a cause of osteoporosis was made by Riggs et al. [176] and more recently it has been demonstrated that acromegalic patients could be at risk of osteoporosis and fractures [177] and vertebral fractures [178]. Following studies clearly demonstrated that trabecular structure of bone is abnormal in relation to biomechanical properties in acromegalic patients compared to controls $[178,179]$ and these patients were at high risk of vertebral fractures, confirming previous observation of an unfavorable effect of chronic excess of $\mathrm{GH}$ on the skeleton. For the first time using quantitative morphometric analysis (a 3D HR-pQCT system) and BMD at lumbar spine and total hip, Bonadonna et al. [180] and Mazziotti et al. [136] found a high prevalence of osteoporotic vertebral fractures in unselected acromegalic patients. This hypothesis, already based on association studies, has been recently confirmed by prospective studies $[181,182]$. Mazziotti et al. after a 3-year follow-up demonstrated a high rate of incident vertebral fractures both in patients with active and controlled acromegaly (42.0\%) compared to controls subjects (3.8\%). Claessen et al. [182] showed that vertebral fractures progress in the long term in $20 \%$ of patients with biochemically controlled acromegaly in the absence of osteoporosis or osteopenia suggesting that an abnormal bone quality persists in these patients after remission, possibly related to pretreatment long-term exposure to high circulating levels of GH. Vertebral fractures may also develop even in patients with normal BMD [180, 183, 184]. Bonadonna et al. [180] 
showed that high numbers of postmenopausal women with acromegaly develop vertebral fractures which occurred even in the presence of normal BMD, whereas, in patients with controlled acromegaly, vertebral fractures were always accompanied by a pathological BMD. In both diabetic and nondiabetic patients, vertebral fractures occurred independently of BMD and suggest that diabetes mellitus may be associated with an increased prevalence of vertebral fractures in males with acromegaly [183]. Acromegalic patients with fractures had significantly higher serum IGF-I values. This effect seems to be relatively attenuated in the presence of persistent GH hypersecretion. Wassenaar et al. [184] found that BMD did not change during prolongation of follow-up by 7 years of controlled acromegaly and the high prevalence of vertebral fractures were independent from BMD. The biochemical control of acromegaly may not be sufficient to normalize the risk of vertebral fractures mainly in patients with hypogonadism. The association of the incidence of vertebral fractures with hypogonadism was significantly higher in patients with active disease [181]. Acromegaly appears to have a deleterious effect on trabecular bone microarchitecture and the gonadal status might be more important than type 2 diabetes mellitus or acromegaly activity in determining bone health [178]. Moreover, patients with fractures showed significantly longer untreated hypogonadism as compared to patients without fractures. The GH/IGF-1 hypersecretion may produce different effects on bone in males and females under the influence of estrogen/testosterone and age [171]. The effect of chronic GH excess on spinal trabecular bone mass seems to be anabolic in active eugonadal patients but not in hypogonadal patients [185]. These data show that although high levels of circulating GH and IGF-1 have an anabolic effect on bone, they alone are not able to maintain BMD and the disadvantageous effect on bone density was associated with hypogonadism in both sexes $[171,185]$. Sex hormones have a crucial role in maintaining the trabecular bone microstructure; the deleterious effects of hypoganadism on bone microstructure have been described in postmenopausal women [186-188] and in men [189] with reduced cortical bone and lower trabecular density and thickness. These data underscore the important interaction of sex steroids with GH/IGF-1 axis on bone metabolism.

11.3. Treatment of Growth Hormone Deficiency (GHD) Patients. GH treatment in GHD adults has a marked effect on markers of bone formation (such as osteocalcin and serum level of $\mathrm{C}$ terminal propeptide), bone resorption (urinary hydroxyproline, collagen cross links, and serum concentration of collagen type I telopeptide), and serum IGF1 levels [190-192]. Trials involving adults or childhood-onset GHD show conflicting results regarding the effect of $\mathrm{GH}$ on bone mass. However, short-term placebo controlled trials have failed to show any increase in BMD or BMC during GH treatment [190, 192-194]. More encouraging results were obtained after more prolonged treatments (12-30 months) [195-198]. In the latter study, 10 years of GH replacement was conducted in hypopituitary adults and a sustained, progressive increase in bone mass and bone density was observed. The study also suggests that adequate estrogen replacement is needed in order to have an optimal response in BMD among GHD women. Elborsson et al. [199], using data from GHD adults with fifteen years of GH replacement with a low dose of $0.6 \mathrm{mg} /$ day, demonstrated a sustained increase in total body and lumbar spine BMC and BMD. In the neck of the femur, BMC and BMD peaked at 7 years and then decreased toward baseline values. Lumbar spine BMC increased by $9 \%$ and BMD by $5 \%$ while in the femur neck the increase in BMC and BMD was $7 \%$ and $3 \%$, respectively. After 15 years, femur neck BMC was 5\% above baseline. Gender differences have been observed in response to GH. Males responded with a high increase in serum osteocalcin, PICP, and CITP concentration, whereas in women a more marked increase in total body BMD was observed [200]. A cross-sectional study reported that vertebral fractures were significantly more frequent in GHD patients versus control subjects and the fracture prevalence, as well as the fracture number, was significantly higher in untreated versus treated patients. The prevalence of spinal deformities was correlated only with the timing of the beginning of $\mathrm{rhGH}$ replacement and not with BMD. The replacement treatment of GHD leads to a significant decrease in fracture rate [201]: recently, the meta-analysis of Barake et al. [202] suggests a beneficial effect of rhGH replacement on BMD in adults with GH deficiency mentioning that larger studies are needed to evaluate the effect of rhGH on fracture risk.

11.4. Senile Osteoporosis. In elderly people, the bone mass declines and the risk of fractures increases [203]. Fragility fractures and impaired or unsuccessful bone healing are the most significant consequences of osteoporosis [204]. Several interacting factors contribute to the risk of osteoporosis, including clinical, medical, behavioral, nutritional, hormonal, and genetic variables $[205,206]$. Sarcopenia and other muscular factors also contribute to bone loss and increased fracture risk in the elderly [207] associated with physical impairment and functional limitation [208]. Both trabecular and periosteal bone formations decline with aging in males and females [209]. The key feature of osteoporosis in postmenopausal women and in aging men was identified in estrogen deficiency. Estrogen plays a dominant multifactorial role in maintaining cortical bone formation by supporting osteoblasts and preventing bone resorption by suppressing osteoclast formation and stimulating osteoclast apoptosis [210]. In the first years after menopause, bone loss accelerates [211] and bone loss continues with the increasing age [212]. In men osteoporosis sustains approximately $30 \%$ of all hip fractures and has a 2-fold excess mortality within the immediate postfracture period [213]. Men also suffer greater functional impairment from severe vertebral deformities compared to women [214] suggesting that factors other than BMD are also important in determining risk [215]. Manolagas [216] provided a paradigm shift from the "estrogen-centric" role of the pathogenesis of osteoporosis to an intrinsic oxidative stress age-related in organs and tissues. The oxidative stress in both animals and humans may be a pivotal pathogenetic mechanism of the age-related bone loss and strength. Loss 
of estrogens or androgens accelerates the effects of aging on bone [16]. The late phase of bone loss in aging women and men is mediated by the increased PTH levels [217]. Aging is associated with a decrease in GH secretion [218] and serum IGF-1 concentration has been reported to be significantly lower in men [219] and women with osteoporosis. Positive relationships between $\mathrm{BMD}$ and serum concentrations of IGF-land IGFBP-3 were observed in healthy men [220]. The circulating level of IGF-1 was found to be an independent predictor of total BMC in healthy elderly women [221] and was significantly lower in men [219] and women with osteoporosis. In addition, IGFBP-3 has been reported to be lower in both males and females with osteoporosis [222]. The age-related increase in PTH secretion was due to the loss of the effects of estrogen on extraskeletal calcium homeostasis and this action seems to be more dominant even in elderly women. Also important to note is that vitamin D deficiency with aging contributes independently to secondary hyperparathyroidism [223]. Aging is also associated with decreases in the amplitude and frequency of $\mathrm{GH}$ secretion [13]; sex and age have independent and interrelated effects on GH secretion. These effects can be largely accounted for by corresponding variations in endogenous estradiol levels amplifying the action on the neuroendocrine regulation of pulsatile GH release [18]. In GHD patients, serum IGF-1 levels are low in females and males, and when $\mathrm{GH}$ therapy is given, females require a higher dose of $\mathrm{GH}$ to get an increase in serum IGF-1 levels similar to males [224] evidencing a $\mathrm{GH}$ resistance to exogenous or endogenous E. Furthermore, circulating IGF-1 is positively associated with aerobic fitness and muscular endurance and in young men is an expression of health and fitness outcomes [225227]. Nutrition is another important factor regulating IGF1 secretion. Changes in free IGF-I and IGFBP-1 are sensitive to caloric restriction [228] and a positive correlation between protein ingestion and bone health has been found [229, 230]. Finally, the aging process is associated with increased serum TNF $\alpha$ levels [231]. This cytokine inhibits bone formation in part by inducing osteoblast apoptosis [232] and the TNF $\alpha$ antagonists have been found to reverse the age-related deficit in bone formation [233].

\section{Effect of the GH/IGF-1 Axis on Bone Metabolism in Patients with Normal GH Secretion}

The GH/IGF-1 axis is one of the major determinants of adult bone mass [234]. It has been well established that GH secretion declines with age [235] and IGF-1 declines in serum and bone [236]. GH and IGF-1 are of primary importance for bone mass in addition to IGFBP-3. A positive relationship between BMD and serum concentrations of IGF-1 and IGFBP-3 was observed in healthy men [7] and rapid decreases in serum IGF-1 levels after menopause might be partly involved in bone loss [237]. Various cross-sectional studies have demonstrated strong relationships between serums IGF-1 and IGFBP-3 and $\mathrm{BMD}$ in postmenopausal women and men [238-240]. In young men, with age under 60 years, the IGF-1 level was a determinant of hip BMD (Szule P, 2004) and low serum IGF-1 levels are associated with increased risk of hip and vertebral fractures by $45 \%$ and $40 \%$, respectively [10]. In elderly women, serum IGF-1 concentration was found to be an independent predictor of total BMC [221] and low levels of IGF-1 have been reported in both males and females with osteoporosis [222].

\section{Effect of GH Administration on Osteoporosis and Bone Metabolism}

The administration of $\mathrm{GH}$ has been evaluated in various clinical trials in normal subject and in osteoporosis and postmenopausal women (Table 1). A great deal of variance exists in the studies in terms of age, dose of GH administered, and duration of the therapy. Studies have reported large differences in age (from 22 to 81 years) and in the administered dose of $\mathrm{GH}$ (from $0.015 \mathrm{mg} / \mathrm{kg} /$ day to $0.75 \mathrm{mg} / \mathrm{kg} /$ day) in addition to the duration of the therapy ranging from 3 days to 3 years. In a large part of the studies a significant increase in bone formation, BMC, and BMD was observed. Firstly Kruse and Kuhlencordt in 1975 [241], in patients with primary and secondary osteoporosis treated with GH, reported an increase in periosteal new bone formation and an intracortical bone resorption with a significantly increased relative osteoblast activity. The effect of GH therapy has been evaluated in healthy subjects [242-245], in postmenopausal osteoporosis [128, 244, 246-256], and in men with idiopatic osteoporosis $[254,257]$. In the most studies a significant bone resorption and bone formation with a prevalent anabolic effect and BMD increased were observed. Only in a few studies the evaluation of BMD by DEXA (Dual-energy X-ray absorptiometry, a mean of measuring BMD) was described [240, 252, 256]. The Landin-Wilhelmsen [255] the longest double blind, randomized placebo-controlled trial, showed conducted for three years, an increase in bone mineral content of $14 \%$ in postmenopausal women with osteoporosis. In a few studies no positive effect of the $\mathrm{GH}$ therapy was observed [244, 246, 248, 252]. In the Saaf study the GH dose administration was reduced by $50 \%$ due to side effects and after one year a reduction of BMD at the femoral neck was observed. The reason for this apparent partial resistance to the anabolic effects of $\mathrm{GH}$ was not clear but nutritional deficits and the low doses of $\mathrm{GH}$ administration were suspected. In the Holloway study the dosage of $\mathrm{GH}$ administered was very low $(0.02 \mathrm{mg} / \mathrm{kg} /$ day $)$ as for the Erdtsieck study $(0.02 \mathrm{mg} / \mathrm{kg} /$ day three times a week). GH administration also restores normal PTH secretory patterns in osteoporotic postmenopausal women, improves target organ sensitivity to PTH, and results in a net positive balance in bone mineral metabolism, all leading to an increase in BMD $[256,258]$. The women receiving estrogen therapy showed a less increment of all bone markers [244] suggesting, in concordance with the data from Ho and Weissberger [259], that hepatic IGF1 generation was suppressed due to oral delivery of estrogen. The most frequent side effects observed due to $\mathrm{GH}$ therapy were fluid retention and carpal tunnel syndrome which disappeared after withdrawal, but generally the therapy was well tolerated. 
TABLE 1: Effect of GH administration on osteoporosis and bone metabolism.

\begin{tabular}{|c|c|c|c|c|c|c|c|c|}
\hline Authors & $\begin{array}{l}\text { Subjects and } \\
\text { clinical } \\
\text { conditions }\end{array}$ & $\begin{array}{l}\text { Age } \\
\text { years }\end{array}$ & $\begin{array}{c}\text { Dose } \\
\mathrm{mg} / \mathrm{kg} / \text { day }\end{array}$ & Duration & $\mathrm{BF}$ & $\mathrm{BR}$ & BMD & Side effect \\
\hline $\begin{array}{l}\text { Kruse and } \\
\text { Kuhlencordt, } 1975 \\
{[241]}\end{array}$ & $3 \mathrm{MO}$ & $58,36,45$ & 1.45 to $2.3 \mathrm{mg} / \mathrm{day}$ & 8 to 15 months & $\uparrow$ & $\uparrow$ & $\begin{array}{l}\text { New periosteal } \\
\text { bone formation } \\
\text { and osteoblasts } \\
\text { significantly } \\
\text { increased }\end{array}$ & $\begin{array}{l}\text { Fluid } \\
\text { retention and } \\
\text { carpal tunnel } \\
\text { syndrome }\end{array}$ \\
\hline $\begin{array}{l}\text { Brixen et al., } 1990 \\
\text { [242] }\end{array}$ & $\begin{array}{c}20 \mathrm{M} \\
\text { healthy }\end{array}$ & $26.5 \pm 5.6$ & 0.06 & 7 days & $\uparrow$ & $\uparrow$ & $\begin{array}{l}\text { BMC got } \\
\text { significantly } \\
\text { higher }\end{array}$ & None \\
\hline $\begin{array}{l}\text { Rudman et al., } \\
1990 \text { [243] }\end{array}$ & $\begin{array}{c}12 \mathrm{M} \\
\text { healthy }\end{array}$ & $72.1 \pm 8.5$ & $0.027 \times 3$ times/week & 6 months & - & - & $\begin{array}{l}\text { Increase in } \\
\text { lumbar vertebral } \\
\text { BMD and in } \\
\text { lean body mass }\end{array}$ & None \\
\hline $\begin{array}{l}\text { Marcus et al.,1990 } \\
{[260]}\end{array}$ & $16 \mathrm{M}$ and $\mathrm{W}$ & 60 & $0.03,0.06$, or 0.12 & 7 days & $\uparrow$ & - & $\begin{array}{l}\text { PTH and } \\
\text { osteocalcin } \\
\text { increased }\end{array}$ & $\begin{array}{c}\text { Impaired oral } \\
\text { glucose } \\
\text { tolerance }\end{array}$ \\
\hline $\begin{array}{l}\text { Clemmesen et al., } \\
1993 \text { [246] }\end{array}$ & $42 \mathrm{PMO}$ & $71.6 \pm 3.0$ & $7.2 \mathrm{mg} /$ week & 12 week & $\uparrow$ & $\uparrow$ & $\begin{array}{l}\text { Bone mass } \\
\text { decreased }\end{array}$ & None \\
\hline $\begin{array}{l}\text { Kassem et al., } \\
1994 \text { [247] }\end{array}$ & $30 \mathrm{PMO}$ & $69 \pm 5.6$ & 0.067 & 3 days & $\uparrow$ & $\uparrow$ & $\begin{array}{l}\text { Significantly } \\
\text { increased } \\
\text { serums IGF-I, } \\
\text { IGF-II, } \\
\text { IGFBP-3, and } \\
\text { IGFBP-4 }\end{array}$ & None \\
\hline $\begin{array}{l}\text { Holloway et al., } \\
1994[244]\end{array}$ & $\begin{array}{l}19 \text { W } \\
\text { healthy }\end{array}$ & $64.6 \pm 2.9$ & 0.02 & 6 months & $\uparrow$ & $\uparrow$ & $\begin{array}{l}\text { No significant } \\
\text { changes at the } \\
\text { lumbar spine } \\
\text { and femoral } \\
\text { neck }\end{array}$ & $\begin{array}{l}\text { Fluid } \\
\text { retention and } \\
\text { carpal tunnel } \\
\text { syndrome }\end{array}$ \\
\hline $\begin{array}{l}\text { Brixen et al., } 1995 \\
\text { [128] }\end{array}$ & $40 \mathrm{PMO}$ & $52-73$ & $0.015-0.03-0.06$ & 7 days & $\uparrow$ & $\uparrow$ & $\begin{array}{l}\text { Dose-dependent } \\
\text { stimulation of } \\
\text { bone formation } \\
\text { and bone } \\
\text { resorption }\end{array}$ & None \\
\hline $\begin{array}{l}\text { Erdtsieck et al., } \\
1995 \text { [248] }\end{array}$ & $21 \mathrm{PMO}$ & $63.5 \pm 9$ & $\begin{array}{l}0.0203 \text { times/week } \\
\text { + pamidronate }\end{array}$ & 1 year & $\uparrow$ & $\uparrow$ & $\begin{array}{l}\text { Blunted the } \\
\text { pamidronate } \\
\text { induced } \\
\text { accumulation of } \\
\text { bone mineral } \\
\text { mass and the } \\
\text { reduction of } \\
\text { bone turnover }\end{array}$ & None \\
\hline $\begin{array}{l}\text { Johansson et al., } \\
1996 \text { [257] }\end{array}$ & $12 \mathrm{MIO}$ & $44 \pm 8$ & $\begin{array}{c}0.60 \mathrm{mg} / \mathrm{m}^{2} \text { or } \\
\text { IGF-I } \\
(80 \mathrm{micrograms} / \mathrm{kg})\end{array}$ & 7 days & $\uparrow$ & $\uparrow$ & $\begin{array}{l}\text { IGF-I enhanced } \\
\text { formation of } \\
\text { collagen type I } \\
\text { more than GH } \\
\text { did }\end{array}$ & None \\
\hline Bianda, 1997 [261] & $\begin{array}{c}7 \mathrm{M} \\
\text { healthy }\end{array}$ & $32 \pm 6.4$ & 3.63 & 5 days & $\uparrow$ & $\uparrow$ & $\begin{array}{l}\text { Bone turnover } \\
\text { and free } \\
\text { calcitriol index } \\
\text { increased }\end{array}$ & None \\
\hline $\begin{array}{l}\text { Holloway et al., } \\
1997 \text { [249] }\end{array}$ & $84 \mathrm{PMO}$ & $69.2 \pm 6.5$ & $\begin{array}{l}0.020 \text { ( } 7 \text { days } \\
\text { followed by } 5 \text { days of } \\
\text { calcitonin } 100 \mathrm{U})\end{array}$ & $\begin{array}{c}2 \text { years } \\
12 \times 56 \text { days } \\
\text { cycles }\end{array}$ & $\uparrow$ & $\uparrow$ & $\begin{array}{l}\text { Significant } \\
\text { increases of } \\
\text { BMD at lumbar } \\
\text { spine and hip in } \\
\text { the combined } \\
\text { GH + CT and } \\
\text { GH + placebo }\end{array}$ & None \\
\hline
\end{tabular}


TABle 1: Continued.

\begin{tabular}{|c|c|c|c|c|c|c|c|c|}
\hline Authors & $\begin{array}{l}\text { Subjects and } \\
\text { clinical } \\
\text { conditions }\end{array}$ & $\begin{array}{l}\text { Age } \\
\text { years }\end{array}$ & $\begin{array}{c}\text { Dose } \\
\mathrm{mg} / \mathrm{kg} / \text { day }\end{array}$ & Duration & $\mathrm{BF}$ & $\mathrm{BR}$ & $\mathrm{BMD}$ & Side effect \\
\hline $\begin{array}{l}\text { Kassem et al., } \\
1998[250]\end{array}$ & $40 \mathrm{PMO}$ & $52-73$ & $0.015-0.03-0.6$ & 7 days & $\uparrow$ & $\uparrow$ & $\begin{array}{l}\text { Significantly } \\
\text { increased } \\
\text { serums IGF-I, } \\
\text { IGF-II, } \\
\text { IGFBP-3, and } \\
\text { IGFBP-4 }\end{array}$ & None \\
\hline $\begin{array}{l}\text { Sugimoto et al., } \\
1999 \text { [251] }\end{array}$ & $8 \mathrm{~F}$ & $71 \pm 3.4$ & $\begin{array}{l}0.038 / \mathrm{kg} / \text { week } \\
\text { followed by } \\
0.075 / \mathrm{kg} / \text { week }\end{array}$ & $\begin{array}{l}4 \text { weeks } \\
48 \text { weeks }\end{array}$ & $\uparrow$ & $\uparrow$ & $\begin{array}{l}\text { Increases in } \\
\text { radial and } \\
\text { lumbar BMD, } \\
\text { effect after } \\
\text { discontinuation } \\
\text { of GH treatment }\end{array}$ & None \\
\hline $\begin{array}{l}\text { Sääf et al., } 1999 \\
\text { [252] }\end{array}$ & $12 \mathrm{PMO}$ & $67.8 \pm 1.1$ & $\begin{array}{c}0,015 \text { and reduced to } \\
50 \%\end{array}$ & 1 year & $\begin{array}{c}\text { No } \\
\text { change }\end{array}$ & $\begin{array}{l}\text { No } \\
\text { change }\end{array}$ & $\begin{array}{l}\text { Decreased BMD } \\
\text { at femoral neck }\end{array}$ & None \\
\hline $\begin{array}{l}\text { Sugimoto et al., } \\
2002 \text { [253] }\end{array}$ & $8 \mathrm{PMO}$ & $72.0 \pm 0.5$ & 0.0054 & 48 weeks & $\uparrow$ & $\uparrow$ & $\begin{array}{l}\text { Radial BMD } \\
\text { significantly } \\
\text { increased after } \\
\text { discontinuation } \\
\text { of GH treatment }\end{array}$ & None \\
\hline $\begin{array}{l}\text { Gillberg et al., } \\
2002 \text { [254] }\end{array}$ & $29 \mathrm{M} \mathrm{IO}$ & $47.8 \pm 9.8$ & 0.36 & 12 months & $\uparrow$ & $\uparrow$ & $\begin{array}{l}\text { Increased BMD } \\
\text { and BMC } \\
\text { sustained for at } \\
\text { least } 1 \mathrm{yr} \text { after } \\
\text { treatment }\end{array}$ & None \\
\hline $\begin{array}{l}\text { Landin- } \\
\text { Wilhelmsen et al., } \\
2003 \text { [255] }\end{array}$ & 80 PMO & $50-70$ & $\begin{array}{c}0.30 \text { or } 0.75 \mathrm{mg} / \text { day } \\
+ \text { estrogen }\end{array}$ & 3 years & $\uparrow$ & $\uparrow$ & $\begin{array}{l}\text { BMC increased } \\
14 \%\end{array}$ & None \\
\hline $\begin{array}{l}\text { Joseph et al., } 2008 \\
\text { [256] }\end{array}$ & $14 \mathrm{PMO}$ & $63.4 \pm 2.0$ & $\begin{array}{c}0.2 \mathrm{mg} / \mathrm{d} \times 4 \mathrm{wk} \\
\text { increments of } \\
0.1 \mathrm{mg} / \mathrm{d} \text { every } 2 \mathrm{wk}\end{array}$ & 12 months & $\uparrow$ & $\uparrow$ & $\begin{array}{l}\text { Net, increase in } \\
\text { BMD, and } \\
\text { sensitivity to } \\
\text { PTH restored }\end{array}$ & None \\
\hline
\end{tabular}

$\mathrm{M}=$ men, $\mathrm{W}$ = women, $\mathrm{PMO}$ = postmenopausal osteoporosis, $\mathrm{MIO}=$ men with idiopatic osteoporosis, $\mathrm{BF}=$ bone formation, $\mathrm{BR}=$ bone resorption, and $\mathrm{BMD}=$ bone mass density.

\section{Effect of IGF-1 Administration on Osteoporosis and Bone Metabolism}

Recombinant human IGF-1 (rhIGF-1) has been used for many years for the treatment of osteoporosis and the clinical studies are reported in Table 2. In clinical studies on this issue, it is evident that age has varied considerably (from 12 to 74 years), which may explain some differences in results. Furthermore, great differences in the dose have been reported (from 0.5 to $240 \mu \mathrm{g} / \mathrm{kg} /$ day) and the duration of the therapy has varied from 1 to 6 days. Significant bone resorption and formation has been demonstrated in all studies and no significant side effects have been reported. An increase in circulating IGF-1, IGFBP-2 and IGFBP-3, and PINP (a bone formation marker) has also been reported. The studies have been performed in varying clinical conditions, including healthy subjects [245, 266, 268], during fasting [265], in osteopenia and anorexia $[267,271,273]$, in postmenopausal osteoporosis [263, 269], in men with osteopenia $[257,262,280]$, osteoporosis in Werner syndrome [264], and during corticoid therapy [159]. In all the studies a positive effect on bone remodeling and increased bone formation was evidenced. Only in one study after longterm IGF-1 administration for 1 year, no differences in bone turnover markers between the IGF-1 treated and placebo treated subjects were found [269]. The negative finding in this investigation could be attributed to the fall of $\mathrm{GH}$ secretion due to IGF-1 administration. Previous studies demonstrated that a low dose IGF-1 treatment increased blood markers for bone formation without increased for resorption markers in osteoporosis of postmenopausal women $[263,266]$ and a dose response effect was described. Long-term studies have shown similar positive effects and generally have shown a good safety record with low dosage recombinant human IGF1 on bone mass. Grinspoon et al. [272] studied low weight, osteopenic girls with anorexia nervosa, and were the first to report that bone turnover falls rapidly with acute caloric deprivation in normal women and rhIGF-1 administration selectively stimulated bone formation in this setting.

Berneis et al. [159] demonstrated that only the combination of $\mathrm{GH}$ and IGF-I, but not GH alone, markedly 
TABLE 2: Effect of IGF-1 administration on osteoporosis and bone metabolism.

\begin{tabular}{|c|c|c|c|c|c|c|c|}
\hline Authors & $n$. subjects & Age & $\begin{array}{l}\text { Dosage } \\
\mu / \mathrm{kg} / \text { day }\end{array}$ & Duration & $\mathrm{BF}$ & $\mathrm{BR}$ & Clinical effects \\
\hline $\begin{array}{l}\text { Johansson et al., } \\
1992 \text { [262] }\end{array}$ & $1 \mathrm{M}$ & - & $80 \mu / \mathrm{kg} /$ day $\times 2$ & & $\uparrow$ & $\uparrow$ & $\begin{array}{l}\text { Bone formation } \\
\text { markers increased }\end{array}$ \\
\hline $\begin{array}{l}\text { Ebeling et al., } \\
1993 \text { [263] }\end{array}$ & $18 \mathrm{PMO}$ & $\begin{array}{c}74 \pm 0.2 \\
66.3 \pm 7.8 \\
67.4 \pm 5.5 \\
58.6 \pm 4.4 \\
\end{array}$ & $\begin{array}{c}30 \\
60 \\
120 \\
180\end{array}$ & 7 days & $\uparrow$ & $\uparrow$ & $\begin{array}{l}\text { Significant } \\
\text { dose-dependent BR, } \\
\text { less BF. Longer } \\
\text { treatments are } \\
\text { suggested } \\
\end{array}$ \\
\hline $\begin{array}{l}\text { Rubin et al., } \\
1994 \text { [264] }\end{array}$ & $\begin{array}{c}1 \mathrm{~W}, \text { Werner } \\
\text { syndrome, low serum } \\
\text { IGF-1 level, and } \\
\text { osteoporosis. }\end{array}$ & - & $30-75$ & 6 months & $\uparrow$ & $\uparrow$ & $\begin{array}{l}\text { Lumbar bone mass } \\
\text { increased 3\% BMD }\end{array}$ \\
\hline $\begin{array}{l}\text { Grinspoon et al., } \\
1995 \text { [265] }\end{array}$ & $14 \mathrm{~W}$ normal & $19-33$ & $100 \mu \times 2$ & 6 days & $\uparrow$ & - & $\begin{array}{l}\text { Increase bone } \\
\text { formation }\end{array}$ \\
\hline $\begin{array}{l}\text { Ghiron et al., } \\
1995 \text { [266] }\end{array}$ & $\begin{array}{c}16 \mathrm{w} \\
\text { healthy }\end{array}$ & $71.9 \pm 1.3$ & $60,15 \mu$ (diet also) & 28 days & $\uparrow$ & $\uparrow$ & Increase bone mass \\
\hline $\begin{array}{l}\text { Johansson et al., } \\
1996 \text { [257] }\end{array}$ & $12 \mathrm{M} \mathrm{IO}$ & $44 \pm 8$ & $80 \mu$ & 7 days & $\uparrow$ & $\uparrow$ & $\begin{array}{l}\text { Enhanced bone } \\
\text { formation and bone } \\
\text { resorption }\end{array}$ \\
\hline $\begin{array}{l}\text { Grinspoon et al., } \\
1996 \text { [267] }\end{array}$ & $23 \mathrm{~W}$ & $18-29$ & $200,60 \mu$ & 6 days & $\uparrow$ & $\uparrow$ & $\begin{array}{l}\text { Increases markers of } \\
\text { bone turnover }\end{array}$ \\
\hline $\begin{array}{l}\text { Mauras et al., } \\
1996 \text { [268] }\end{array}$ & $\begin{array}{l}5 \mathrm{M}+3 \mathrm{~W} \\
3 \mathrm{M}+2 \mathrm{~W}\end{array}$ & $\begin{array}{l}23-27 \\
23-25\end{array}$ & $\begin{array}{l}240 \mu \\
100 \mu\end{array}$ & 5-7 days & $\uparrow$ & $\uparrow$ & $\begin{array}{l}\text { Synergize with sex } \\
\text { steroids to maximally } \\
\text { stimulate attainment } \\
\text { of peak bone mass in } \\
\text { humans }\end{array}$ \\
\hline $\begin{array}{l}\text { Bianda et al., } \\
1997 \text { [245] }\end{array}$ & $7 \mathrm{M}$ & & $192 \mu$ & 5 days & $\uparrow$ & $\uparrow$ & $\begin{array}{l}\text { Serum osteocalcin } \\
\text { and PICP, the urinary } \\
\text { deoxypyridino- } \\
\text { line/creatinine, and } \\
\text { calcium/creatinine } \\
\text { ratios got significantly } \\
\text { higher }\end{array}$ \\
\hline $\begin{array}{l}\text { Berneis et al., } \\
1999 \text { [159] }\end{array}$ & $\begin{array}{c}24 \mathrm{M} \\
\text { healthy }\end{array}$ & $24.5 \pm 1.2$ & $\begin{array}{c}\mathrm{GH}=0.15 \times \\
2 \mathrm{IU} / \mathrm{kg} / \text { day } \\
\quad+ \\
\mathrm{IGF}-1=80 \mu\end{array}$ & 6 days & - & - & $\begin{array}{l}\text { Markedly counteracts } \\
\text { diminished bone and } \\
\text { body collagen } \\
\text { synthesis caused by } \\
\text { glucocorticoids }\end{array}$ \\
\hline $\begin{array}{l}\text { Friedlander et } \\
\text { al., 2001 [269] }\end{array}$ & $24 \mathrm{PMO}$ & $72 \pm 2.7$ & $15 \mu / \mathrm{kg}$ twice daily & 1 year & $\uparrow$ & $\uparrow$ & No effect \\
\hline $\begin{array}{l}\text { Boonen et al., } \\
2002[270]\end{array}$ & $30 \mathrm{~W}$ & $65-90$ & $0.5-1 \mu / \mathrm{kg} / \mathrm{d}$ & 8 weeks & $\uparrow$ & $\uparrow$ & $\begin{array}{l}\text { Effects on bone mass, } \\
\text { muscle strength, and } \\
\text { functional ability, } \\
\text { beneficial trends }\end{array}$ \\
\hline $\begin{array}{l}\text { Grinspoon et al., } \\
2002[271]\end{array}$ & $\begin{array}{c}60 \mathrm{~W} \\
\text { osteopenia } \\
\text { with anorexia }\end{array}$ & $18-38$ & $\begin{array}{l}30 \mu \mathrm{g} / \mathrm{kg} \mathrm{sc} \\
\text { twice daily }\end{array}$ & 9 months & $\uparrow$ & - & $\begin{array}{l}\text { Increased mIGFBP-2 } \\
\text { and decreased } \\
\text { IGFBP-3 and bone } \\
\text { density increased }\end{array}$ \\
\hline $\begin{array}{l}\text { Grinspoon et al., } \\
2003 \text { [272] }\end{array}$ & $\begin{array}{c}65 \mathrm{~W} \\
\text { anorexia } \\
\text { nervosa }\end{array}$ & $25.6 \pm 0.8$ & $\begin{array}{l}30 \mu \mathrm{g} / \mathrm{kg} \mathrm{sc} \\
\text { twice daily }\end{array}$ & 9 months & - & - & $\begin{array}{l}\text { IGF-I and IGFBP-3 } \\
\text { are independent } \\
\text { predictors of bone } \\
\text { density }\end{array}$ \\
\hline $\begin{array}{l}\text { Misra et al., } \\
2009 \text { [273] }\end{array}$ & $\begin{array}{c}10 \mathrm{~W} \\
\text { low bone } \\
\text { density and anorexia }\end{array}$ & $12-18$ & $\begin{array}{l}30-40 \mathrm{mcg} / \mathrm{k} \\
\text { twice daily }\end{array}$ & 7-9 days & $\uparrow$ & $\uparrow$ & $\begin{array}{l}\text { Increase in PINP, a } \\
\text { bone formation } \\
\text { marker }\end{array}$ \\
\hline
\end{tabular}

$\mathrm{M}=$ men, $\mathrm{W}=$ women, $\mathrm{PMO}=$ postmenopausal women, $\mathrm{MIO}=$ men with idiopatic osteoporosis, $\mathrm{BR}=$ bone resorption, $\mathrm{BF}=$ bone formation. 
counteracts the diminished bone and body collagen synthesis caused by glucocorticoids. The free testosterone index was lower in these patients. In conclusion it looks that short- and long-term treatment with IGF-1 stimulates bone resorption and bone formation considerably with prevalent anabolic effect and produced minimal or no side effects.

\section{Effect of GH/IGF-1 on Fracture Healing}

The complexity of the fracture repair process has been reported since its first histologic description. In a fractured bone the healing process is initiated by the formation of a thick periosteal callus of woven bone with a central area of cartilage. Endochondral ossification of the cartilage occurs subsequently in the woven bone. Later a marked remodeling process is activated and the callus volume declines while the density is enhanced. In epiphyseal plate after fracture the healing was accompanied by an increase in DNA content, by a change in cellular activity, and by greatly accelerated apoptosis [281]. Various cellular mediators (bone morphogenetic proteins, interleukins, and angiogenic growth factors) in healing bone are involved [282]. The potential for growth and differentiation factors, such as the use of BMPs to enhance fracture healing in the clinical setting is still controversial [283]. In tibiae of micropigs it has been demonstrated that callus area, bone area, cartilage area, and bone perimeter were regenerated after $\mathrm{GH}$ administration and that $\mathrm{GH}$ promotes bone formation and maturation of the regenerate without disturbing the callus structure [284].

Many experimental and clinical studies have found that growth factors, such as morphogenetic proteins (MPs) [285], the fibroblastic-like growth factors family (FGFs) [286], transforming growth factors (TGFs) [287], and plateledderived growth factors (PDGF) [288], stimulate bone formation during fracture healing. However, these hormones require local application which leads to difficult administration due to limited accessibility to the fracture site. Evidences suggests that these hormones can also influence bone healing in patients who have sustained head injury with a more intensive callus formation than those without head injury $[289,290]$ and one injury to one part of the skeleton increases bone formation at a distal skeleton site [291] indicating that systemic humoral mechanisms may enhance bone formation. The GH/IGF-1 axis is involved in the biochemical mechanisms determining delayed or failed fracture healing [292]. The clinical trials conducted on the effect of administration of rhGH or rhIGF-1 on bone healing are reported in Table 3.

The studies evidenced a significant effect of GH treatment on bone healing in patients after surgery for hip or tibial fractures. The range of dose of administration varied from 0.02 to $0.06 \mathrm{mg} / \mathrm{kg} /$ day. Various studies have investigated the effect of GH therapy in hip fractures [274-277] all reporting a positive effect on bone healing and functional outcome. Two studies have investigated the effect of GH therapy on tibial fractures. In one study [279] dose dependent markers of bone formation were described and the biochemical markers of bone turnover persist until eight or twelve weeks after the cessation of treatment. Raschke et al. [278] performed a randomized double-blind placebo-controlled trial of $\mathrm{GH}$ treatment at different doses $(15,30$, and $60 \mu \mathrm{g} / \mathrm{kg} /$ day $)$, in a group of open and closed tibial fractures, and reported no significant enhancement of fracture healing. The reason of this $\mathrm{GH}$ resistance could be related to a minimum increment in IGF-1 (from 201 to $218 \mathrm{ng} / \mathrm{mL}$ ) and in IGFBP-3 (from 2.5 to $2.9 \mathrm{mg} / \mathrm{L}$ ) and other factors could have interfered with the GH effect, such as nutritional and inflammatory status. Only one study reported the effect of IGF-1 on bone healing [270]. In this study a protein complex rhIGF-I/IGFBP-3 in the treatment of 20 women affected by hip fractures was used and indicated that this treatment at a dose of $1 \mathrm{mg} / \mathrm{kg} / \mathrm{d}$ stimulates bone metabolism in frail osteoporotic patients and the muscular efficiency increased. Placebo-treated subjects had an average bone mineral loss at the contralateral hip of about $6 \%$ during the first 6 months after the injury. The IGF1 serum level is significantly associated with the ability to function after hip fracture in women [293]. GH therapy is also helpful for prevention of fracture risk in $\mathrm{GH}$ deficient subjects [294]. In a recent review [295], the effectiveness of GH on hip fracture healing was evaluated and treatment showed that IGF-1 levels significantly increased in the short term, but no significant differences occur in the long term. Only one study measuring BMC showed no significant differences in the change of the BMD scores between $\mathrm{GH}$ and placebo groups and only one trial reported the measurement of BMC. The latter trial showed that $\mathrm{GH}$ had no effect while the placebo group lost BMC at both 4 and 8 weeks. With the low quality of current evidence, GH may be effective in hip fractures. More carefully designed, double-blinded and placebo-controlled randomized trials with large numbers of participants are needed to better evaluate the effects of $\mathrm{GH}$ in the treatment of the various fractures.

\section{GH Resistance}

The development of $\mathrm{GH}$ resistance is one of the most important metabolic derangements observed in patients with systemic infection, major trauma, and burn injuries [296, 297]. GH resistance probably has a multifactorial origin. The clinical consequences of $\mathrm{GH}$ resistance include weight loss (particularly lean body mass), impaired wound healing, prolonged recovery, and impaired survival [298]. It is likely that both the fasting state and circulating factors, possibly inflammatory cytokines, such as TNF and IL-1, are etiological factors [298-300]. Data from in vitro studies and animal models suggest that increased levels of inflammatory cytokines can induce cachexia and might inhibit the effects of $\mathrm{GH}$ on target tissues. During sepsis, growth hormone (GH) resistance contributes to the catabolism of muscle protein suggesting that TNF mediates hepatic GH resistance during sepsis by inhibiting the duration of signaling via the Janus kinase-2/STAT5 pathway [301]. It has been demonstrated that the inhibitory effects of interleukin-1 on growth hormone action during catabolic illness [298] and also Interleukine6 inhibit growth hormone-mediated gene expression in hepatocytes [302], so the liver becomes unresponsive to 
TABLE 3: Effect of GH and IGF-1 administration on bone fractures healing.

\begin{tabular}{|c|c|c|c|c|c|c|c|}
\hline Authors & $\begin{array}{c}\text { Number of } \\
\text { subjects }\end{array}$ & Age & Type of fracture & Therapy & $\begin{array}{c}\text { Dose GH } \\
\text { (mg/kg/day) }\end{array}$ & Duration & Results \\
\hline $\begin{array}{l}\text { Van der Lely et al., } \\
2000[274]\end{array}$ & $\begin{array}{c}\text { Placebo }=46 \\
W=42 \\
M=13\end{array}$ & $\begin{array}{l}76.5 \pm 7.2 \\
23.6 \pm 3.2\end{array}$ & Hip fracture & rHGH & 0.02 & 6 weeks & $\begin{array}{l}75 \% \text { of patients } \\
\text { return to the } \\
\text { prefracture } \\
\text { living situation }\end{array}$ \\
\hline $\begin{array}{l}\text { Boonen et al., } 2002 \\
{[270]}\end{array}$ & $9 \mathrm{M}+11 \mathrm{~W}$ & $65-90$ & Hip fracture & $\begin{array}{l}\text { rhIGF- } \\
\text { I/IGFBP-3 }\end{array}$ & $\begin{array}{l}0.5=9 \\
1.0=11\end{array}$ & $\begin{array}{l}8 \text { weeks } \\
6 \text { months }\end{array}$ & $\begin{array}{l}\text { Increase } \\
\text { bone density } \\
\text { and muscle } \\
\text { strength and } \\
\text { enhance } \\
\text { functional } \\
\text { recovery }\end{array}$ \\
\hline $\begin{array}{l}\text { Yeo et al., } 2003 \\
{[275]}\end{array}$ & $31 \mathrm{~W}$ & $\begin{array}{c}86 \\
\text { medium }\end{array}$ & Hip fracture & rHGH & $\begin{array}{c}0.05 \text { (high dose) } \\
\text { or } \\
0.025 \text { (low dose) }\end{array}$ & 14 days & $\begin{array}{l}\text { Significant } \\
\text { increase of } \\
\text { serum IGF-I } \\
\text { and IGFBP-3 } \\
\text { and promotes } \\
\text { anabolism }\end{array}$ \\
\hline $\begin{array}{l}\text { Weissberger et al., } \\
2003 \text { [276] }\end{array}$ & $33 \mathrm{~W}$ & $60-82$ & $\begin{array}{l}\text { Total hip } \\
\text { replacement }\end{array}$ & rHGH & 0.012 & $\begin{array}{l}14 \text { weeks } \\
\text { preoperatively } \\
\text { and } 4 \text { weeks } \\
\text { postoperatively }\end{array}$ & $\begin{array}{l}\text { Improvements } \\
\text { in lean body } \\
\text { mass and } \\
\text { skeletal muscle } \\
\text { mass }\end{array}$ \\
\hline $\begin{array}{l}\text { Hedström et al., } \\
2004 \text { [277] }\end{array}$ & $20 \mathrm{~W}$ & $<65$ & Hip fracture & rHGH & $0.1 \mathrm{U} \max 8 \mathrm{U}$ & 4 weeks & $\begin{array}{l}\text { IGF-I increased } \\
\text { significantly and } \\
\text { lean body mass } \\
\text { and BMC } \\
\text { preserved }\end{array}$ \\
\hline $\begin{array}{l}\text { Raschke et al., } 2007 \\
\text { [278] }\end{array}$ & $\begin{array}{c}406 \\
93 \mathrm{~W}+ \\
313 \mathrm{M}\end{array}$ & $18-64$ & Tibial fracture & rHGH & 15,30 , or 60 & 16 weeks & $\begin{array}{l}\text { GH did not } \\
\text { accelerate time } \\
\text { to healing in } \\
\text { open fracture }\end{array}$ \\
\hline $\begin{array}{l}\text { Krusenstjerna- } \\
\text { Hafstrøm et al., } \\
2011 \text { [279] }\end{array}$ & $\begin{array}{c}406 \\
\text { (313 males } \\
\text { and } 93 \\
\text { females) }\end{array}$ & $56 \pm 8.4$ & Tibial fracture & rHGH & 15,30 , or 60 & 16 weeks & $\begin{array}{l}\text { Dose-dependent } \\
\text { increases of } \\
\text { bone markers* }\end{array}$ \\
\hline
\end{tabular}

$\mathrm{M}=$ men, $\mathrm{W}=$ women .

growth hormone. Resistance or insensitivity is characterized by higher GH levels, low IGF-1 levels, and a reduced anabolic response to $\mathrm{GH}$. This aspect must be considered before starting a therapeutic program with $\mathrm{GH}$ in patients after surgery or with an active inflammation process because $\mathrm{GH}$ resistance could inhibit $\mathrm{GH}$ effects.

\section{Cancer Risk Related to GH and IGF-1 Administration}

The GH and IGFs have mitogenic and proliferative properties and the potential risk in tumor promotion and progression has been suspected [303, 304], but various studies have demonstrated that this risk is uncertain. Deodati et al. [305] assessed systematically the association between $\mathrm{GH}$ therapy and all-cause, cancer and cardiovascular mortality, cancer morbidity, and risk of second neoplasm mainly in patients treated during childhood and adolescence. Malignancy and cardiovascular SMRs were not significantly increased. The overall cancer incidence and the relative risk for second neoplasms were significantly increased. Carel et al. [306] found that the mortality rates were increased in a population of adults treated from childhood age with recombinant $\mathrm{GH}$, particularly in those who had received the highest doses. Specific effects were detected in terms of death due to bone tumors or cerebral hemorrhage but not for all cancers.

In a long-term mortality study none of the patients died from cancer or from a cardiovascular disease [307]. In $\mathrm{GH}$-deficient adults treated with $\mathrm{GH}$ the occurrence of malignancies was not higher than in the general population [308]. In cancer survivors treated with GH the elevation of risk of developing a second neoplasm due to $\mathrm{GH}$ use appears to diminish with increasing length of follow-up [309]. Higher IGFBP-2 and/or IGFBP-3 may be associated with increased cancer risk [310], but a recent meta-analysis evidenced that the IGFBP-3 polymorphisms are not associated with 
colorectal cancer susceptibility [311]. In patients who received GH treatment after 24 weeks and 48 weeks side effects were small, with no significant differences between subgroups [312]. The data may raise concern on the long-term safety of $\mathrm{GH}$ treatment, but for short time therapy only minimal side effects, such as fluid retention or articular pain, were described.

\section{Conclusions}

GH and IGF-1 have a great effect on bone resorption and bone anabolism and their administration has a positive effect on osteoporosis and fracture healing. Androgen and estrogen interact with GH and IGF-1 optimizing bone mass acquisition with prevalent effect of androgen $[89,313]$. Sex steroids are critical for skeletal growth and maintenance. While IGF1 has a great effect on bone resorption at trabecular level, androgens play a fundamental role on bone activating directly and indirectly the AR increasing the trabecular and periosteal bone growth. The optimal stimulation is obtained in the presence of both AR and ER activation and a minimum for $\mathrm{E}$ level is necessary in men for bone maturation [314]. The effect of GH and IGF-1 therapy on bone osteoporosis and fracture healing is mediated by many factors that can realize a $\mathrm{GH}$ resistance: inflammatory cytokines, sex hormones levels, nutritional deficiency, and muscle mass and strength. More carefully designed, double-blind, and placebo-controlled randomized trials with large numbers of participants regarding GH plus sex hormone treatment of osteoporosis and bone healing after fractures are required.

\section{Conflict of Interests}

The authors declare that there is no conflict of interests regarding the publication of this paper.

\section{Acknowledgment}

Acknowledgment to Professor Francesco Minuto, Department of Endocrinology, University of Genova, is due for the collaboration in the revision of the paper.

\section{References}

[1] R. Bouillon and A. Prodonova, "Growth hormone deficiency and peak bone mass," Journal of Pediatric Endocrinology \& Metabolism, vol. 13, supplement 6, pp. 1327-1336, 2000.

[2] A. M. Boot, M. A. M. J. Engels, G. J. M. Boerma, E. P. Krenning, and S. M. P. F. de Muinck Keizer-Schrama, "Changes in bone mineral density, body composition, and lipid metabolism during growth hormone (GH) treatment in children with GH deficiency," Journal of Clinical Endocrinology and Metabolism, vol. 82, no. 8, pp. 2423-2428, 1997.

[3] A. Giustina, G. Mazziotti, and E. Canalis, "Growth hormone, insulin-like growth factors, and the skeleton," Endocrine Reviews, vol. 29, no. 5, pp. 535-559, 2008.

[4] E. Barrett-Connor and D. Goodman-Gruen, "Gender differences in insulin-like growth factor and bone mineral density association in old age: the rancho Bernardo study," Journal of Bone and Mineral Research, vol. 13, no. 8, pp. 1343-1349, 1998.

[5] J. A. Langlois, C. J. Rosen, M. Visser et al., "Association between insulin-like growth factor I and bone mineral density in older women and men: the Framingham heart study," Journal of Clinical Endocrinology and Metabolism, vol. 83, no. 12, pp. 42574262, 1998.

[6] J. A. M. J. L. Janssen, H. Burger, R. P. Stolk et al., "Genderspecific relationship between serum free and total IGF-I and bone mineral density in elderly men and women," European Journal of Endocrinology, vol. 138, no. 6, pp. 627-632, 1998.

[7] A. G. Johansson, A. Forslund, L. Hambraeus, W. F. Blum, and S. Ljunghall, "Growth hormone-dependent insulin-like growth factor binding protein is a major determinant of bone mineral density in healthy men," Journal of Bone and Mineral Research, vol. 9, no. 6, pp. 915-921, 1994.

[8] T. Sugimoto, K. Nishiyama, F. Kuribayashi, and K. Chihara, "Serum levels of insulin-like growth factor (IGF) I, IGF-binding protein (IGFBP)-2, and IGFBP-3 in osteoporotic patients with and without spinal fractures," Journal of Bone and Mineral Research, vol. 12, no. 8, pp. 1272-1279, 1997.

[9] P. Garnero, E. Sornay-Rendu, and P. D. Delmas, "Low serum IGF-1 and occurrence of osteoporotic fractures in postmenopausal women," The Lancet, vol. 355, no. 9207, pp. 898899, 2000.

[10] C. Ohlsson, D. Mellström, D. Carlzon et al., "Older men with low serum IGF-1 have an increased risk of incident fractures: the MrOS Sweden study," Journal of Bone and Mineral Research, vol. 26, no. 4, pp. 865-872, 2011.

[11] I. Kanazawa, T. Yamaguchi, M. Yamamoto, M. Yamauchi, S. Yano, and T. Sugimoto, "Serum insulin-like growth factor-I level is associated with the presence of vertebral fractures in postmenopausal women with type 2 diabetes mellitus," Osteoporosis International, vol. 18, no. 12, pp. 1675-1681, 2007.

[12] P. R. Ebeling, L. M. Atley, J. R. Guthrie et al., "Bone turnover markers and bone density across the menopausal transition," Journal of Clinical Endocrinology \& Metabolism, vol. 81, no. 9, pp. 3366-3371, 1996.

[13] K. Y. Ho, W. S. Evans, R. M. Blizzard et al., "Effects of sex and age on the 24-hour profile of growth hormone secretion in man: importance of endogenous estradiol concentrations," Journal of Clinical Endocrinology and Metabolism, vol. 64, no. 1, pp. 51-58, 1987.

[14] P. Szulc, M. O. Joly-Pharaboz, F. Marchand, and P. D. Delmas, "Insulin-like growth factor I is a determinant of Hip bone mineral density in men less than 60 years of age: MINOS study," Calcified Tissue International, vol. 74, no. 4, pp. 322-329, 2004.

[15] E. Seeman, "Estrogen, androgen, and the pathogenesis of bone fragility in women and men," Current Osteoporosis Reports, vol. 2, no. 3, pp. 90-96, 2004.

[16] M. Almeida, L. Han, M. Martin-Millan et al., "Skeletal involution by age-associated oxidative stress and its acceleration by loss of sex steroids," Journal of Biological Chemistry, vol. 282, no. 37, pp. 27285-27297, 2007.

[17] S. Yakar, H. Courtland, and D. Clemmons, "IGF-1 and bone: new discoveries from mouse models," Journal of Bone and Mineral Research, vol. 25, no. 12, pp. 2543-2552, 2010.

[18] J. C. Fritton, K. B. Emerton, H. Sun et al., "Growth hormone protects against ovariectomy-induced bone loss in states of low circulating Insulin-like Growth Factor (IGF-1)," Journal of Bone and Mineral Research, vol. 25, no. 2, pp. 235-246, 2010. 
[19] A. Giustina and J. D. Veldhuis, "Pathophysiology of the neuroregulation of growth hormone secretion in experimental animals and the human," Endocrine Reviews, vol. 19, no. 6, pp. 717-797, 1998.

[20] J. R. Florini, D. Z. Ewton, and S. A. Coolican, "Growth hormone and the insulin-like growth factor system in myogenesis," Endocrine Reviews, vol. 17, no. 5, pp. 481-517, 1996.

[21] S. Feld and R. Hirschberg, "Insulinlike growth factor I and the kidney," Trends in Endocrinology \& Metabolism, vol. 7, no. 3, pp. 85-93, 1996.

[22] G. Goldspink and S. D. R. Harridge, "Growth factors and muscle ageing," Experimental Gerontology, vol. 39, no. 10, pp. 1433-1438, 2004.

[23] D. Aberg, "Role of the growth hormone/insulin-like growth factor 1 axis in neurogenesis," Endocrine Development, vol. 17, pp. 63-76, 2010.

[24] C. Ohlsson, B. Bengtsson, O. G. P. Isaksson, T. T. Andreassen, and M. C. Slootweg, "Growth hormone and bone," Endocrine Reviews, vol. 19, no. 1, pp. 55-79, 1998.

[25] M. Ballesteros, K. Leung, R. J. M. Ross, T. P. Iismaa, and K. K. Y. Ho, "Distribution and abundance of messenger ribonucleic acid for growth hormone receptor isoforms in human tissues," Journal of Clinical Endocrinology and Metabolism, vol. 85, no. 8, pp. 2865-2871, 2000.

[26] S. Yakar, J.-L. Liu, B. Stannard et al., "Normal growth and development in the absence of hepatic insulin-like growth factor I," Proceedings of the National Academy of Sciences of the United States of America, vol. 96, no. 13, pp. 7324-7329, 1999.

[27] J.-P. Liu, J. Baker, A. S. Perkins, E. J. Robertson, and A. Efstratiadis, "Mice carrying null mutations of the genes encoding insulin-like growth factor I (Igf-1) and type 1 IGF receptor (Igflr)," Cell, vol. 75, no. 1, pp. 59-72, 1993.

[28] K. Sjögren, J. Liu, K. Blad et al., "Liver-derived insulin-like growth factor I (IGF-I) is the principal source of IGF-I in blood but is not required for postnatal body growth in mice," Proceedings of the National Academy of Sciences of the United States of America, vol. 96, no. 12, pp. 7088-7092, 1999.

[29] J. Holly and C. Perks, "The role of insulin-like growth factor binding proteins," Neuroendocrinology, vol. 83, no. 3-4, pp. 154$160,2006$.

[30] C. J. Rosen, L. R. Donahue, and S. J. Hunter, "Insulin-like growth factors and bone: the osteoporosis connection," Proceedings of the Society for Experimental Biology and Medicine, vol. 206, no. 2, pp. 83-102, 1994.

[31] N. Goldenberg and A. Barkan, "Factors regulating growth hormone secretion in humans," Endocrinology and Metabolism Clinics of North America, vol. 36, no. 1, pp. 37-55, 2007.

[32] J. I. Jones and D. R. Clemmons, "Insulin-like growth factors and their binding proteins: biological actions," Endocrine Reviews, vol. 16, no. 1, pp. 3-34, 1995.

[33] C. M. Bagi, R. Brommage, L. Deleon, S. Adams, D. Rosen, and A. Sommer, "Benefit of systemically administered rhIGF-I and rhIGF-I/IGFBP-3 on cancellous bone in ovariectomized rats," Journal of Bone and Mineral Research, vol. 9, no. 8, pp. 1301-1312, 1994.

[34] C. Carter-Su and L. S. Smit, "Signaling via JAK tyrosine kinases: growth hormone receptor as a model system," Recent Progress in Hormone Research, vol. 53, pp. 61-83, 1998.

[35] S. F. Ahmed and C. Farquharson, "The effect of GH and IGF1 on linear growth and skeletal development and their modulation by SOCS proteins," Journal of Endocrinology, vol. 206, no. 3, pp. 249-259, 2010.

[36] V. E. Macrae, S. Horvat, S. C. Pells et al., "Increased bone mass, altered trabecular architecture and modified growth plate organization in the growing skeleton of SOCS2 deficient mice," Journal of Cellular Physiology, vol. 218, no. 2, pp. 276-284, 2009.

[37] P. Bang, M. Westgren, J. Schwander, W. F. Blum, R. G. Rosenfeld, and M. Stangenberg, "Ontogeny of insulin-like growth factorbinding protein-1, -2, and -3: quantitative measurements by radioimmunoassay in human fetal serum," Pediatric Research, vol. 36, no. 4, pp. 528-536, 1994.

[38] G. P. Baumann, "Growth hormone isoforms," Growth Hormone and IGF Research, vol. 19, no. 4, pp. 333-340, 2009.

[39] J. Frystyk, P. Freda, and D. R. Clemmons, "The current status of IGF-I assays-a 2009 update," Growth Hormone \& IGF Research, vol. 20, no. 1, pp. 8-18, 2010.

[40] I. Bancos, A. Algeciras-Schimnich, W. W. Woodmansee et al., "Determination of nadir growth hormone concentration cutoff in patients with acromegaly," Endocrine Practice, vol. 19, no. 6, pp. 937-945, 2013.

[41] A. W. van Toorenenbergen, "Between-laboratory quality control of automated analysis of IgG antibodies against Aspergillus fumigatus," Diagnostic Microbiology and Infectious Disease, vol. 74, no. 3, pp. 278-281, 2012.

[42] J. D. Faix, "Principles and pitfalls of free hormone measurements," Best Practice \& Research Clinical Endocrinology \& Metabolism, vol. 27, no. 5, pp. 631-645, 2013.

[43] W. D. Salmon Jr. and W. H. Daughaday, "A hormonally controlled serum factor which stimulates sulfate incorporation by cartilage in vitro," The Journal of Laboratory and Clinical Medicine, vol. 49, no. 6, pp. 825-836, 1957.

[44] N. L. Schlechter, S. M. Russell, S. Greenberg, E. M. Spencer, and C. S. Nicoll, "A direct growth effect of growth hormone in rat hindlimb shown by arterial infusion," American Journal of Physiology-Endocrinology and Metabolism, vol. 250, no. 3, part 1, pp. E231-E235, 1986.

[45] H. Green, M. Morikawa, and T. Nixon, "A dual effector theory of growth-hormone action," Differentiation, vol. 29, no. 3, pp. 195-198, 1985.

[46] A. Lindahl, J. Isgaard, A. Nilsson, and O. G. P. Isaksson, "Growth hormone potentiates colony formation of epiphyseal chondrocytes in suspension culture," Endocrinology, vol. 118, no. 5, pp. 1843-1848, 1986.

[47] C. Ohlsson, A. Nilsson, O. Isaksson, and A. Lindahl, "Growth hormone induces multiplication of the slowly cycling germinal cells of the rat tibial growth plate," Proceedings of the National Academy of Sciences of the United States of America, vol. 89, no. 20, pp. 9826-9830, 1992.

[48] M. Kassem, L. Mosekilde, and E. F. Eriksen, "Growth hormone stimulates proliferation of normal human bone marrow stromal osteoblast precursor cells in vitro," Growth Regulation, vol. 4, no. 3, pp. 131-135, 1994.

[49] A. Nilsson, D. Swolin, S. Enerback, and C. Ohlsson, "Expression of functional growth hormone receptors in cultured human osteoblast-like cells," The Journal of Clinical Endocrinology \& Metabolism, vol. 80, no. 12, pp. 3483-3488, 1995.

[50] M. Ernst and G. A. Rodan, "Increased activity of insulin-like growth factor (IGF) in osteoblastic cells in the presence of growth hormone $(\mathrm{GH})$ : positive correlation with the presence of the GH-induced IGF-binding protein BP-3," Endocrinology, vol. 127, no. 2, pp. 807-814, 1990. 
[51] Z. Laron and B. Klinger, "IGF-I treatment of adult patients with Laron syndrome: preliminary results," Clinical Endocrinology, vol. 41, no. 5, pp. 631-638, 1994.

[52] M. B. Ranke, M. O. Savage, P. G. Chatelain et al., "Insulinlike growth factor I improves height in growth hormone insensitivity: two years' results," Hormone Research, vol. 44, no. 6, pp. 253-264, 1995.

[53] J. L. Walker, J. J. Van Wyk, and L. E. Underwood, "Stimulation of statural growth by recombinant insulin-like growth factor I in a child with growth hormone insensitivity syndrome (Laron type)," Journal of Pediatrics, vol. 121, no. 4, pp. 641-646, 1992.

[54] J. Guevara-Aguirre, A. L. Rosenbloom, O. Vasconez et al., “Twoyear treatment of growth hormone $(\mathrm{GH})$ receptor deficiency with recombinant insulin-like growth factor I in 22 children: comparison of two dosage levels and to GH-treated GH deficiency," Journal of Clinical Endocrinology and Metabolism, vol. 82, no. 2, pp. 629-633, 1997.

[55] P. F. Collett-Solberg, M. Misra, and Drug and Therapeutics Committee of the Lawson Wilkins Pediatric Endocrine, "The role of recombinant human insulin-like growth factorI in treating children with short stature," Journal of Clinical Endocrinology \& Metabolism, vol. 93, no. 1, pp. 10-18, 2008.

[56] C. J. Rosen and J. P. Bilezikian, "Clinical review 123: anabolic therapy for osteoporosis," The Journal of Clinical Endocrinology \& Metabolism, vol. 86, no. 3, pp. 957-964, 2001.

[57] O. G. P. Isaksson, J. O. Jansson, and I. A. M. Gause, "Growth hormone stimulates longitudinal bone growth directly," Science, vol. 216, no. 4551, pp. 1237-1239, 1982.

[58] J. Isgaard, C. Moller, O. G. P. Isaksson, A. Nilsson, L. S. Mathews, and G. Norstedt, "Regulation of insulin-like growth factor messenger ribonucleic acid in rat growth plate by growth hormone," Endocrinology, vol. 122, no. 4, pp. 1515-1520, 1988.

[59] E. B. Hunziker, J. Wagner, and J. Zapf, "Differential effects of insulin-like growth factor I and growth hormone on developmental stages of rat growth plate chondrocytes in vivo," Journal of Clinical Investigation, vol. 93, no. 3, pp. 1078-1086, 1994.

[60] H. P. Guler, J. Zapf, E. Scheiwiller, and E. R. Froesch, "Recombinant human insulin-like growth factor I stimulates growth and has distinct effects on organ size in hypophysectomized rats.", Proceedings of the National Academy of Sciences of the United States of America, vol. 85, no. 13, pp. 4889-4893, 1988.

[61] S. R. Kupfer, L. E. Underwood, R. C. Baxter, and D. R. Clemmons, "Enhancement of the anabolic effects of growth hormone and insulin-like growth factor I by use of both agents simultaneously," Journal of Clinical Investigation, vol. 91, no. 2, pp. 391-396, 1993.

[62] P. J. Fielder, D. L. Mortensen, P. Mallet, B. Carlsson, R. C. Baxter, and R. G. Clark, "Differential long-term effects of insulin-like growth factor-I (IGF-I), growth hormone (GH), and IGF-I plus GH on body growth and IGF binding proteins in hypophysectomized rats," Endocrinology, vol. 137, no. 5, pp. 1913-1920, 1996.

[63] S. J. Hazel, C. M. Gillespie, R. J. Moore, R. G. Clark, K. F. Jureidini, and A. A. Martin, "Enhanced body growth in uremic rats treated with IGF-I and growth hormone in combination," Kidney International, vol. 46, no. 1, pp. 58-68, 1994.

[64] N. A. Sims, P. Clément-Lacroix, F. da Ponte et al., "Bone homeostasis in growth hormone receptor-null mice is restored by IGF-I but independent of Stat5," The Journal of Clinical Investigation, vol. 106, no. 9, pp. 1095-1103, 2000.
[65] H. Courtland, S. Elis, Y. Wu et al., "Serum IGF-1 affects skeletal acquisition in a temporal and compartment-specific manner," PLoS ONE, vol. 6, no. 3, Article ID e14762, 2011.

[66] L. Laviola, A. Natalicchio, S. Perrini, and F. Giorgino, "Abnormalities of IGF-I signaling in the pathogenesis of diseases of the bone, brain, and fetoplacental unit in humans," The American Journal of Physiology: Endocrinology and Metabolism, vol. 295, no. 5, pp. E991-E999, 2008.

[67] S. Yakar, E. Canalis, H. Sun et al., "Serum IGF-1 determines skeletal strength by regulating subperiosteal expansion and trait interactions," Journal of Bone and Mineral Research, vol. 24, no. 8, pp. 1481-1492, 2009.

[68] M. Zhang, S. Xuan, M. L. Bouxsein et al., "Osteoblast-specific knockout of the insulin-like growth factor (IGF) receptor gene reveals an essential role of IGF signaling in bone matrix mineralization," Journal of Biological Chemistry, vol. 277 , no. 46, pp. 44005-44012, 2002.

[69] S. Yakar, C. J. Rosen, W. G. Beamer et al., "Circulating levels of IGF-1 directly regulate bone growth and density," Journal of Clinical Investigation, vol. 110, no. 6, pp. 771-781, 2002.

[70] H. Uronen-Hansson, M. L. Allen, E. Lichtarowicz-Krynska et al., "Growth hormone enhances proinflammatory cytokine production by monocytes in whole blood," Growth Hormone and IGF Research, vol. 13, no. 5, pp. 282-286, 2003.

[71] G. Renier, I. Clément, A. C. Desfaits, and A. Lambert, “Direct stimulatory effect of insulin-like growth factor-I on monocyte and macrophage tumor necrosis factor- $\alpha$ production," Endocrinology, vol. 137, no. 11, pp. 4611-4618, 1996.

[72] M. Wolf, S. Bohm, M. Brand, and G. Kreymann, "Proinflammatory cytokines interleukin $1-\beta$ and tumor necrosis factor $\alpha$ inhibit growth hormone stimulation of insulin-like growth factor I synthesis and growth hormone receptor mRNA levels in cultured rat liver cells," European Journal of Endocrinology, vol. 135, no. 6, pp. 729-737, 1996.

[73] D. Swolin and C. Ohlsson, "Growth hormone increases interleukin-6 produced by human osteoblast- like cells," Journal of Clinical Endocrinology and Metabolism, vol. 81, no. 12, pp. 43294333, 1996.

[74] T. Yamaguchi, M. Kanatani, M. Yamauchi et al., "Serum levels of insulin-like growth factor (IGF); IGF-binding proteins-3, -4, and -5 ; and their relationships to bone mineral density and the risk of vertebral fractures in postmenopausal women," Calcified Tissue International, vol. 78, no. 1, pp. 18-24, 2006.

[75] S. Boonen, S. Mohan, J. Dequeker et al., "Down-regulation of the serum stimulatory components of the insulin-like growth factor (IGF) system (IGF-I, IGF-II, IGF binding protein [BP]-3, and IGFBP-5) in age-related (type II) femoral neck osteoporosis," Journal of Bone and Mineral Research, vol. 14, no. 12, pp. 2150-2158, 1999.

[76] T. Seck, C. Scheidt-Nave, G. Leidig-Bruckner, R. Ziegler, and J. Pfeilschifter, "Low serum concentrations of insulin-like growth factor I are associated with femoral bone loss in a populationbased sample of postmenopausal women," Clinical Endocrinology, vol. 55, no. 1, pp. 101-106, 2001.

[77] G. E. Krassas, P. Papadopoulou, G. Koliakos, T. Konstantinidis, and K. Kalothetou, "Growth hormone, insulin growth factor-1, and IGF binding protein-3 axis relationship with bone mineral density among healthy men," Archives of Andrology, vol. 49, no. 3, pp. 191-199, 2003.

[78] P. M. Yamada and K. W. Lee, "Perspectives in mammalian IGFBP-3 biology: local vs. systemic action," The American 
Journal of Physiology—Cell Physiology, vol. 296, no. 5, pp. C954C976, 2009.

[79] O. Ali, P. Cohen, and K.-W. Lee, "Epidemiology and biology of insulin-like growth factor binding protein-3 (IGFBP-3) as an anti-cancer molecule," Hormone and Metabolic Research, vol. 35, no. 11-12, pp. 726-733, 2003.

[80] S. Benini, M. Zuntini, M. C. Manara et al., "Insulin-like growth factor binding protein 3 as an anticancer molecule in Ewing's sarcoma," International Journal of Cancer, vol. 119, no. 5, pp. 1039-1046, 2006.

[81] I. Niemann, A. Hannemann, M. Nauck et al., "The association between insulin-like growth factor I and bone turnover markers in the general adult population," Bone, vol. 56, no. 1, pp. 184-190, 2013.

[82] S. C. Manolagas, "Birth and death of bone cells: basic regulatory mechanisms and implications for the pathogenesis and treatment of osteoporosis," Endocrine Reviews, vol. 21, no. 2, pp. 115137, 2000.

[83] M. Beato and J. Klug, "Steroid hormone receptors: an update," Human Reproduction Update, vol. 6, no. 3, pp. 225-236, 2000.

[84] S. C. Manolagas, C. A. O’Brien, and M. Almeida, "The role of estrogen and androgen receptors in bone health and disease," Nature Reviews Endocrinology, vol. 9, no. 12, pp. 699-712, 2013.

[85] D. S. Colvard, E. F. Eriksen, P. E. Keeting et al., "Identification of androgen receptors in normal human osteoblast-like cells," Proceedings of the National Academy of Sciences of the United States of America, vol. 86, no. 3, pp. 854-857, 1989.

[86] C. Ohlsson and L. V. Vandenput, "The role of estrogens for male bone health," European Journal of Endocrinology, vol. 160, no. 6, pp. 883-889, 2009.

[87] H. Kawano, H. Kawaguchi, and S. Kato, "Bone metabolism in androgen receptor-deficient mice," Clinical Calcium, vol. 13, no. 11, pp. 1443-1445, 2003.

[88] A. J. Notini, J. F. McManus, A. Moore et al., "Osteoblast deletion of exon 3 of the androgen receptor gene results in trabecular bone loss in adult male mice," Journal of Bone and Mineral Research, vol. 22, no. 3, pp. 347-356, 2007.

[89] F. Callewaert, M. Sinnesael, E. Gielen, S. Boonen, and D. Vanderschueren, "Skeletal sexual dimorphism: relative contribution of sex steroids, GH-IGF1, and mechanical loading," Journal of Endocrinology, vol. 207, no. 2, pp. 127-134, 2010.

[90] S. Kousteni, T. Bellido, L. I. Plotkin et al., "Nongenotropic, sex-nonspecific signaling through the estrogen or androgen receptors: dissociation from transcriptional activity," Cell, vol. 104, no. 5, pp. 719-730, 2001.

[91] D. J. Benz, M. R. Haussler, M. A. Thomas, B. Speelman, and B. S. Komm, "High-affinity androgen binding and androgenic regulation of $\alpha 1$ (I)-procollagen and transforming growth factor$\beta$ steady state messenger ribonucleic acid levels in human osteoblast-like osteosarcoma cells," Endocrinology, vol. 128, no. 6, pp. 2723-2730, 1991.

[92] J. P. Bilezikian, A. Morishima, J. Bell, and M. M. Grumbach, "Increased bone mass as a result of estrogen therapy in a man with aromatase deficiency," The New England Journal of Medicine, vol. 339, no. 9, pp. 599-603, 1998.

[93] V. Coxam, B. M. Bowman, M. Mecham, C. M. Roth, M. A. Miller, and S. C. Miller, "Effects of dihydrotestosterone alone and combined with estrogen on bone mineral density, bone growth, and formation rates in ovariectomized rats," Bone, vol. 19, no. 2, pp. 107-114, 1996.
[94] A. Tomkinson, J. Reeve, R. W. Shaw, and B. S. Noble, “The death of osteocytes via apoptosis accompanies estrogen withdrawal in human bone," Journal of Clinical Endocrinology and Metabolism, vol. 82, no. 9, pp. 3128-3135, 1997.

[95] M. Martin-Millan, M. Almeida, E. Ambrogini et al., “The estrogen receptor- $\alpha$ in osteoclasts mediates the protective effects of estrogens on cancellous but not cortical bone," Molecular Endocrinology, vol. 24, no. 2, pp. 323-334, 2010.

[96] S. H. Windahl, L. Saxon, A. E. Börjesson et al., "Estrogen receptor- $\alpha$ is required for the osteogenic response to mechanical loading in a ligand-independent manner involving its activation function 1 but not 2," Journal of Bone and Mineral Research, vol. 28, no. 2, pp. 291-301, 2013.

[97] R. Marcus, D. Leary, D. L. Schneider, E. Shane, M. Favus, and C. A. Quigley, "The contribution of testosterone to skeletal development and maintenance: lessons from the androgen insensitivity syndrome," Journal of Clinical Endocrinology and Metabolism, vol. 85, no. 3, pp. 1032-1037, 2000.

[98] H. Kawano, T. Sato, T. Yamada et al., "Suppressive function of androgen receptor in bone resorption," Proceedings of the National Academy of Sciences of the United States of America, vol. 100, no. 16, pp. 9416-9421, 2003.

[99] K. M. Wiren, A. A. Semirale, X. W. Zhang et al., "Targeting of androgen receptor in bone reveals a lack of androgen anabolic action and inhibition of osteogenesis : a model for compartment-specific androgen action in the skeleton," Bone, vol. 43, no. 3, pp. 440-451, 2008.

[100] S. Khosla, M. J. Oursler, and D. G. Monroe, "Estrogen and the skeleton," Trends in Endocrinology and Metabolism, vol. 23, no. 11, pp. 576-581, 2012.

[101] A. Falahati-Nini, B. L. Riggs, E. J. Atkinson, W. M. O’Fallon, R. Eastell, and S. Khosla, "Relative contributions of testosterone and estrogen in regulating bone resorption and formation in normal elderly men," Journal of Clinical Investigation, vol. 106, no. 12, pp. 1553-1560, 2000.

[102] L. Mosekilde, J. S. Thomsen, P. B. Orhii, and D. N. Kalu, "Growth hormone increases vertebral and femoral bone strength in osteopenic, ovariectomized, aged rats in a dose-dependent and site-specific manner," Bone, vol. 23, no. 4, pp. 343-352, 1998.

[103] Y. Kasukawa, L. Stabnov, N. Miyakoshi, D. J. Baylink, and S. Mohan, "Insulin-like growth factor I effect on the number of osteoblast progenitors is impaired in ovariectomized mice," Journal of Bone and Mineral Research, vol. 17, no. 9, pp. 15791587, 2002.

[104] J. K. Yeh, M. Chen, and J. F. Aloia, "Effects of estrogen and growth hormone on skeleton in the ovariectomized rat with hypophysectomy," The American Journal of Physiology Endocrinology and Metabolism, vol. 273, no. 4, pp. E734-E742, 1997.

[105] L. S. Kidder, I. U. Schmidt, G. L. Evans, and R. T. Turner, "Effects of growth hormone and low dose estrogen on bone growth and turnover in long bones of hypophysectomized rats," Calcified Tissue International, vol. 61, no. 4, pp. 327-335, 1997.

[106] T. Abe, J. W. M. Chow, J. M. Lean, and T. J. Chambers, "Estrogen does not restore bone lost after ovariectomy in the rat," Journal of Bone and Mineral Research, vol. 8, no. 7, pp. 831-838, 1993.

[107] G. K. Wakley, G. L. Evans, and R. T. Turner, "Short-term effects of high dose estrogen on tibiae of growing male rats," Calcified Tissue International, vol. 60, no. 1, pp. 37-42, 1997.

[108] J. D. Veldhuis, J. Frystyk, A. Iranmanesh, and H. Ørskov, “Testosterone and estradiol regulate free insulin-like growth factor 
I (IGF-I), IGF binding protein 1 (IGFBP-1), and dimeric IGFI/IGFBP-1 concentrations," Journal of Clinical Endocrinology and Metabolism, vol. 90, no. 5, pp. 2941-2947, 2005.

[109] A. J. Weissberger, K. K. Ho, and L. Lazarus, "Contrasting effects of oral and transdermal routes of estrogen replacement therapy on 24-hour growth hormone (GH) secretion, insulin-like growth factor I, and GH-binding protein in postmenopausal women," Journal of Clinical Endocrinology and Metabolism, vol. 72, no. 2, pp. 374-381, 1991.

[110] L. Vandenput, S. Boonen, E. Van Herck, J. V. Swinnen, R. Bouillon, and D. Vanderschueren, "Evidence from the aged orchidectomized male rat model that $17 \beta$-estradiol is a more effective bone-sparing and anabolic agent than $5 \alpha$-dihydrotestosterone," Journal of Bone and Mineral Research, vol. 17, no. 11, pp. 20802086, 2002.

[111] J. J. Christiansen, S. Fisker, C. H. Gravholt et al., "Discontinuation of estrogen replacement therapy in GH-treated hypopituitary women alters androgen status and IGF-I," European Journal of Endocrinology, vol. 152, no. 5, pp. 719-726, 2005.

[112] D. Vanderschueren, L. Vandenput, S. Boonen, M. K. Lindberg, R. Bouillon, and C. Ohlsson, "Androgens and bone," Endocrine Reviews, vol. 25, no. 3, pp. 389-425, 2004.

[113] C. H. Kasperk, J. E. Wergedal, J. R. Farley, T. A. Linkhart, R. T. Turner, and D. J. Baylink, "Androgens directly stimulate proliferation of bone cells in vitro," Endocrinology, vol. 124, no. 3, pp. 1576-1578, 1989.

[114] L. X. Bi, K. M. Wiren, X. W. Zhang et al., "The effect of oxandrolone treatment on human osteoblastic cells," Journal of Burns and Wounds, vol. 6, article e4, 2007.

[115] K. Venken, K. De Gendt, S. Boonen et al., "Relative impact of androgen and estrogen receptor activation in the effects of androgens on trabecular and cortical bone in growing male mice: a study in the androgen receptor knockout mouse model," Journal of Bone and Mineral Research, vol. 21, no. 4, pp. 576-585, 2006.

[116] G. Prakasam, J. K. Yeh, M. Chen, M. Castro-Magana, C. T. Liang, and J. F. Aloia, "Effects of growth hormone and testosterone on cortical bone formation and bone density in aged orchiectomized rats," Bone, vol. 24, no. 5, pp. 491-497, 1999.

[117] A. J. Weissberger and K. K. Y. Ho, "Activation of the somatotropic axis by testosterone in adult males: evidence for the role of aromatization," Journal of Clinical Endocrinology and Metabolism, vol. 76, no. 6, pp. 1407-1412, 1993.

[118] H. K. Gleeson and S. M. Shalet, "Effect of aromatizable and unaromatizable androgen replacement in hypogonadal men on GH responsiveness," Clinical Endocrinology, vol. 70, no. 1, pp. 109-115, 2009.

[119] D. Vanderschueren, S. Boonen, A. G. H. Ederveen et al., "Skeletal effects of estrogen deficiency as induced by an aromatase inhibitor in an aged male rat model," Bone, vol. 27, no. 5, pp. 611-617, 2000.

[120] D. Vanderschueren, E. Van Herck, A. M. H. Suiker, W. J. Visser, L. P. C. Schot, and R. Bouillon, "Bone and mineral metabolism in aged male rats: short and long term effects of androgen deficiency," Endocrinology, vol. 130, no. 5, pp. 2906-2916, 1992.

[121] A. E. Kearns and S. Khosla, "Potential anabolic effects of androgens on bone," Mayo Clinic Proceedings, vol. 79, no. 4, pp. S14-S18, 2004.

[122] C. J. Hobbs, S. R. Plymate, C. J. Rosen, and R. A. Adler, “Testosterone administration increases insulin-like growth factor-I levels in normal men," The Journal of Clinical Endocrinology \& Metabolism, vol. 77, no. 3, pp. 776-779, 1993.
[123] L. Liu, G. R. Merriam, and R. J. Sherins, "Chronic sex steroid exposure increases mean plasma growth hormone concentration and pulse amplitude in men with isolated hypogonadotropic hypogonadism," Journal of Clinical Endocrinology and Metabolism, vol. 64, no. 4, pp. 651-656, 1987.

[124] J. O. L. Jørgensen, N. Vahl, T. B. Hansen et al., "Determinants of serum insulin-like growth factor I in growth hormone deficient adults as compared to healthy subjects," Clinical Endocrinology, vol. 48, no. 4, pp. 479-486, 1998.

[125] C. Chiang, M. Chiu, A. J. Moore et al., "Mineralization and bone resorption are regulated by the androgen receptor in male mice," Journal of Bone and Mineral Research, vol. 24, no. 4, pp. 621-631, 2009.

[126] T. L. Andersen, T. E. Sondergaard, K. E. Skorzynska et al., "A physical mechanism for coupling bone resorption and formation in adult human bone," The American Journal of Pathology, vol. 174, no. 1, pp. 239-247, 2009.

[127] M. Kassem, W. Blum, J. Ristelli, L. Mosekilde, and E. F. Eriksen, "Growth hormone stimulates proliferation and differentiation of normal human osteoblast-like cells in vitro," Calcified Tissue International, vol. 52, no. 3, pp. 222-226, 1993.

[128] K. Brixen, M. Kassem, H. K. Nielsen, A. G. Loft, A. Flyvbjerg, and L. Mosekilde, "Short-term treatment with growth hormone stimulates osteoblastic and osteoclastic activity in osteopenic postmenopausal women: a dose response study," Journal of Bone and Mineral Research, vol. 10, no. 12, pp. 1865-1874, 1995.

[129] V. Krishnan, H. U. Bryant, and O. A. MacDougald, "Regulation of bone mass by Wnt signaling," Journal of Clinical Investigation, vol. 116, no. 5, pp. 1202-1209, 2006.

[130] H. Clevers, "Wnt/ $\beta$-catenin signaling in development and disease," Cell, vol. 127, no. 3, pp. 469-480, 2006.

[131] M. F. Cole, S. E. Johnstone, J. J. Newman, M. H. Kagey, and R. A. Young, "Tcf3 is an integral component of the core regulatory circuitry of embryonic stem cells," Genes and Development, vol. 22, no. 6, pp. 746-755, 2008.

[132] E. Canalis, V. Deregowski, R. C. Pereira, and E. Gazzerro, "Signals that determine the fate of osteoblastic cells," Journal of Endocrinological Investigation, vol. 28, no. 8, pp. 3-7, 2005.

[133] M. Takeuchi, H. Kakushi, and M. Tohkin, "Androgens directly stimulate mineralization and increase androgen receptors in human osteoblast-like osteosarcoma cells," Biochemical and Biophysical Research Communications, vol. 204, no. 2, pp. 905911, 1994.

[134] P. Hou, T. Sato, W. Hofstetter, and N. T. Foged, "Identification and characterization of the insulin-like growth factor I receptor in mature rabbit osteoclasts," Journal of Bone and Mineral Research, vol. 12, no. 4, pp. 534-540, 1997.

[135] T. Niu and C. J. Rosen, "The insulin-like growth factor-I gene and osteoporosis: a critical appraisal," Gene, vol. 361, no. 1-2, pp. 38-56, 2005.

[136] G. Mazziotti, A. Bianchi, S. Bonadonna et al., "Prevalence of vertebral fractures in men with acromegaly," Journal of Clinical Endocrinology and Metabolism, vol. 93, no. 12, pp. 4649-4655, 2008.

[137] T. L. McCarthy and M. Centrella, "Regulation of IGF activity in bone," Advances in Experimental Medicine and Biology, vol. 343, pp. 407-414, 1993.

[138] D. P. Bichell, P. Rotwein, and T. L. McCarthy, "Prostaglandin E2 rapidly stimulates insulin-like growth factor-I gene expression in primary rat osteoblast cultures: Evidence for transcriptional control," Endocrinology, vol. 133, no. 3, pp. 1020-1028, 1993. 
[139] E. Canalis, M. Centrella, W. Burch, and T. L. McCarthy, "Insulin-like growth factor I mediates selective anabolic effects of parathyroid hormone in bone cultures," Journal of Clinical Investigation, vol. 83, no. 1, pp. 60-65, 1989.

[140] T. L. Mccarthy, M. Centrella, L. G. Raisz, and E. Canalis, "Prostaglandin E2 stimulates insulin-like growth factor I synthesis in osteoblast-enriched cultures from fetal rat bone," Endocrinology, vol. 128, no. 6, pp. 2895-2900, 1991.

[141] R. M. Locklin, S. Khosla, R. T. Turner, and B. L. Riggs, "Mediators of the biphasic responses of bone to intermittent and continuously administered parathyroid hormone," Journal of Cellular Biochemistry, vol. 89, no. 1, pp. 180-190, 2003.

[142] T. Ishizuya, S. Yokose, M. Hori et al., "Parathyroid hormone exerts disparate effects on osteoblast differentiation depending on exposure time in rat osteoblastic cells," Journal of Clinical Investigation, vol. 99, no. 12, pp. 2961-2970, 1997.

[143] M. Kassem and P. J. Marie, "Senescence-associated intrinsic mechanisms of osteoblast dysfunctions," Aging Cell, vol. 10, no. 2, pp. 191-197, 2011.

[144] S. Amin, B. L. Riggs, L. J. Melton III, S. J. Achenbach, E. J. Atkinson, and S. Khosla, "High serum IGFBP-2 is predictive of increased bone turnover in aging men and women," Journal of Bone and Mineral Research, vol. 22, no. 6, pp. 799-807, 2007.

[145] D. J. DiGirolamo, A. Mukherjee, K. Fulzele et al., "Mode of growth hormone action in osteoblasts," The Journal of Biological Chemistry, vol. 282, no. 43, pp. 31666-31674, 2007.

[146] C. T. Rubin, S. D. Bain, and K. J. McLeod, "Suppression of the osteogenic response in the aging skeleton," Calcified Tissue International, vol. 50, no. 4, pp. 306-313, 1992.

[147] S. L. Bass, P. Eser, and R. Daly, "The effect of exercise and nutrition on the mechanostat," Journal of Musculoskeletal Neuronal Interactions, vol. 5, no. 3, pp. 239-254, 2005.

[148] J. P. Bonjour, "Protein intake and bone health," International Journal for Vitamin and Nutrition Research, vol. 81, no. 2-3, pp. 134-142, 2011.

[149] A. Simkin, J. Ayalon, and I. Leichter, "Increased trabecular bone density due to bone-loading exercises in postmenopausal osteoporotic women," Calcified Tissue International, vol. 40, no. 2, pp. 59-63, 1987.

[150] G. A. Kelley and K. S. Kelley, "Exercise and bone mineral density at the femoral neck in postmenopausal women: a metaanalysis of controlled clinical trials with individual patient data," American Journal of Obstetrics and Gynecology, vol. 194, no. 3, pp. 760-767, 2006.

[151] M. Martyn-St James and S. Carroll, "A meta-analysis of impact exercise on postmenopausal bone loss: the case for mixed loading exercise programmes," British Journal of Sports Medicine, vol. 43, no. 12, pp. 898-908, 2009.

[152] K. T. Borer, "Physical activity in the prevention and amelioration of osteoporosis in women: Interaction of mechanical, hormonal and dietary factors," Sports Medicine, vol. 35, no. 9, pp. 779-830, 2005.

[153] K. Landin-Wilhelmsen, P. A. Lundberg, G. Lappas, and L. Wilhelmsen, "Insulin-like growth factor I levels in healthy adults," Hormone Research, vol. 62, supplement 1, pp. 8-16, 2004.

[154] A. E. Bennett, H. W. Wahner, B. L. Riggs, and R. L. Hintz, "Insulin-like growth factors I and II: aging and bone density in women," Journal of Clinical Endocrinology and Metabolism, vol. 59, no. 4, pp. 701-704, 1984.

[155] F. Callewaert, K. Venken, J. J. Kopchick et al., "Sexual dimorphism in cortical bone size and strength but not density is determined by independent and time-specific actions of sex steroids and IGF-1: evidence from pubertal mouse models," Journal of Bone and Mineral Research, vol. 25, no. 3, pp. 617-626, 2010.

[156] Y. Wu, H. Sun, J. Basta-Pljakic et al., "Serum IGF-1 is insufficient to restore skeletal size in the total absence of the growth hormone receptor," Journal of Bone and Mineral Research, vol. 28, no. 7, pp. 1575-1586, 2013.

[157] S. Bonadonna, A. Burattin, M. Nuzzo et al., "Chronic glucocorticoid treatment alters spontaneous pulsatile parathyroid hormone secretory dynamics in human subjects," European Journal of Endocrinology, vol. 152, no. 2, pp. 199-205, 2005.

[158] S. C. Manolagas and R. S. Weinstein, "New developments in the pathogenesis and treatment of steroid-induced osteoporosis," Journal of Bone and Mineral Research, vol. 14, no. 7, pp. 10611066, 1999.

[159] K. Berneis, M. Oehri, M. Kraenzlin, and U. Keller, "Effects of IGF-I combined with GH on glucocorticoid-induced changes of bone and connective tissue turnover in man," Journal of Endocrinology, vol. 162, no. 2, pp. 259-264, 1999.

[160] S. Melmed, "Acromegaly," The New England Journal of Medicine, vol. 322, no. 14, pp. 966-977, 1990.

[161] S. Ezzat, S. Melmed, D. Endres, D. R. Eyre, and F. R. Singer, "Biochemical assessment of bone formation and resorption in acromegaly," Journal of Clinical Endocrinology and Metabolism, vol. 76, no. 6, pp. 1452-1457, 1993.

[162] M. Marazuela, B. Astigarraga, M. J. Tabuenca, J. Estrada, F. Marin, and T. Lucas, "Serum bone Gla protein as a marker of bone turnover in acromegaly," Calcified Tissue International, vol. 52, no. 6, pp. 419-421, 1993.

[163] A. Scillitani, C. Battista, I. Chiodini et al., "Bone mineral density in acromegaly: the effect of gender, disease activity and gonadal status," Clinical Endocrinology, vol. 58, no. 6, pp. 725-731, 2003.

[164] H. Kotzmann, P. Bernecker, P. Hubsch et al., "Bone mineral density and parameters of bone metabolism in patients with acromegaly," Journal of Bone and Mineral Research, vol. 8, no. 4, pp. 459-466, 1993.

[165] G. P. Lesse, W. D. Fraser, R. Farquharson, L. Hipkin, and J. P. Vora, "Gonadal status is an important determinant of bone density in acromegaly," Clinical Endocrinology, vol. 48, no. 1, pp. 59-65, 1998.

[166] H. Kaji, T. Sugimoto, D. Nakaoka et al., "Bone metabolism and body composition in Japanese patients with active acromegaly," Clinical Endocrinology, vol. 55, no. 2, pp. 175-181, 2001.

[167] P. J. Ho, L. M. Fig, A. L. Barkan, and B. Shapiro, "Bone mineral density of the axial skeleton in acromegaly," Journal of Nuclear Medicine, vol. 33, no. 9, pp. 1608-1612, 1992.

[168] M. J. Kayath and J. G. H. Vieira, "Osteopenia occurs in a minority of patients with acromegaly and is predominant in the spine," Osteoporosis International, vol. 7, no. 3, pp. 226-230, 1997.

[169] I. Chiodini, V. Trischitta, V. Carnevale, A. Liuzzi, and A. Scillitani, "Bone mineral density in acromegaly: does growth hormone excess protect against osteoporosis?" Journal of Endocrinological Investigation, vol. 24, no. 4, pp. 288-291, 2001.

[170] M. Bolanowski, W. Wielgus, A. Milewicz, and R. Marciniak, "Axial bone mineral density in patients with acromegaly," Academic Radiology, vol. 7, no. 8, pp. 592-594, 2000.

[171] W. Zgliczynski, M. Kochman, W. Misiorowski, and P. Zdunowski, "In acromegaly, increased bone mineral density (BMD) is determined by GH-excess, gonadal function and gender," Neuroendocrinology Letters, vol. 28, no. 5, pp. 621-628, 2007. 
[172] P. Vestergaard and L. Mosekilde, "Fracture risk is decreased in acromegaly-a potential beneficial effect of growth hormone," Osteoporosis International, vol. 15, no. 2, pp. 155-159, 2004.

[173] N. R. Biermasz, N. A. T. Hamdy, A. M. Pereira, J. A. Romijn, and F. Roelfsema, "Long-term maintenance of the anabolic effects of GH on the skeleton in successful treated patients with acromegaly," European Journal of Endocrinology, vol. 152, no. 1, pp. 53-60, 2005.

[174] P. Broulik, J. Kragstrup, L. Mosekilde, and F. Melsen, "Osteon cross-sectional size in the iliac crest. Variation in normals and patients with osteoporosis, hyperparathyroidism, acromegaly, hypothyroidism and treated epilepsia," Acta Pathologica et Microbiologica Scandinavica A: Pathology, vol. 90, no. 5, pp. 339-344, 1982.

[175] J. Halse, F. Melsen, and L. Mosekilde, "Iliac crest bone mass and remodelling in acromegaly," Acta Endocrinologica, vol. 97, no. 1, pp. 18-22, 1981.

[176] B. L. Riggs, R. V. Randall, H. W. Wahner, J. Jowsey, P. J. Kelly, and M. Singh, "The nature of the metabolic bone disorder in acromegaly." The Journal of Clinical Endocrinology \& Metabolism, vol. 34, no. 6, pp. 911-918, 1972.

[177] G. Padova, G. Borzì, L. Incorvaia et al., "Prevalence of osteoporosis and vertebral fractures in acromegalic patients," Clinical Cases in Mineral and Bone Metabolism, vol. 8, no. 3, pp. 37-43, 2011.

[178] M. Madeira, L. V. Neto, F. de Paula Paranhos Neto et al., "Acromegaly has a negative influence on trabecular bone, but not on cortical bone, as assessed by high-resolution peripheral quantitative computed tomography," Journal of Clinical Endocrinology and Metabolism, vol. 98, no. 4, pp. 1734-1741, 2013.

[179] T. Ueland, E. N. Ebbesen, J. S. Thomsen et al., "Decreased trabecular bone biomechanical competence, apparent density, IGF-II and IGFBP-5 content in acromegaly," European Journal of Clinical Investigation, vol. 32, no. 2, pp. 122-128, 2002.

[180] S. Bonadonna, G. Mazziotti, M. Nuzzo et al., "Increased prevalence of radiological spinal deformities in active acromegaly: a cross-sectional study in postmenopausal women," Journal of Bone and Mineral Research, vol. 20, no. 10, pp. 1837-1844, 2005.

[181] G. Mazziotti, A. Bianchi, T. Porcelli et al., "Vertebral fractures in patients with acromegaly: a 3-year prospective study," Journal of Clinical Endocrinology and Metabolism, vol. 98, no. 8, pp. 34023410, 2013.

[182] K. M. Claessen, H. M. Kroon, A. M. Pereira et al., "Progression of vertebral fractures despite long-term biochemical control of acromegaly: a prospective follow-up study," Journal of Clinical Endocrinology \& Metabolism, vol. 98, no. 12, pp. 4808-4815, Dec 2013.

[183] G. Mazziotti, M. Gola, A. Bianchi et al., "Influence of diabetes mellitus on vertebral fractures in men with acromegaly," Endocrine, vol. 40, no. 1, pp. 102-108, 2011.

[184] M. J. E. Wassenaar, N. R. Biermasz, N. A. T. Hamdy et al., "High prevalence of vertebral fractures despite normal bone mineral density in patients with long-term controlled acromegaly," European Journal of Endocrinology, vol. 164, no. 4, pp. 475-483, 2011.

[185] C. Battista, I. Chiodini, S. Muscarella et al., "Spinal volumetric trabecular bone mass in acromegalic patients: a longitudinal study," Clinical Endocrinology, vol. 70, no. 3, pp. 378-382, 2009.

[186] S. Boutroy, M. L. Bouxsein, F. Munoz, and P. D. Delmas, "In vivo assessment of trabecular bone microarchitecture by high-resolution peripheral quantitative computed tomography," The Journal of Clinical Endocrinology \& Metabolism, vol. 90, no. 12, pp. 6508-6515, 2005.

[187] K. M. Nicks, S. Amin, E. J. Atkinson, B. L. Riggs, L. J. Melton III, and S. Khosla, "Relationship of age to bone microstructure independent of areal bone mineral density," Journal of Bone and Mineral Research, vol. 27, no. 3, pp. 637-644, 2012.

[188] K. K. Nishiyama, H. M. Macdonald, H. R. Buie, D. A. Hanley, and S. K. Boyd, "Postmenopausal women with osteopenia have higher cortical porosity and thinner cortices at the distal radius and tibia than women with normal aBMD: an in vivo HR-pQCT study," Journal of Bone and Mineral Research, vol. 25, no. 4, pp. 882-890, 2010.

[189] T. Argoud, S. Boutroy, B. Claustrat, R. Chapurlat, and P. Szulc, "Association between sex steroid levels and bone microarchitecture in men: the STRAMBO study," The Journal of Clinical Endocrinology \& Metabolism, vol. 99, no. 4, pp. 1400-1410, 2014.

[190] S. J. Holmes, R. W. Whitehouse, R. Swindell, G. Economou, J. E. Adams, and S. M. Shalet, "Effect of growth hormone replacement on bone mass in adults with adult onset growth hormone deficiency," Clinical Endocrinology, vol. 42, no. 6, pp. 627-633, 1995.

[191] G. Amato, G. Izzo, G. La Montagna, and A. Bellastella, "Low dose recombinant human growth hormone normalizes bone metabolism and cortical bone density and improves trabecular bone density in growth hormone deficient adults without causing adverse effects," Clinical Endocrinology, vol. 45, no. 1, pp. 27-32, 1996.

[192] T. B. Hansen, K. Brixen, N. Vahl et al., "Effects of 12 months of growth hormone $(\mathrm{GH})$ treatment on calciotropic hormones, calcium homeostasis, and bone metabolism in adults with acquired GH deficiency: a double blind, randomized, placebo-controlled study," Journal of Clinical Endocrinology and Metabolism, vol. 81, no. 9, pp. 3352-3359, 1996.

[193] M. Thoren, M. Soop, M. Degerblad, and M. Saaf, "Preliminary study of the effects of growth hormone substitution therapy on bone mineral density and serum osteocalcin levels in adults with growth hormone deficiency," Acta Endocrinologica,, vol. 128, supplement 2, pp. 41-43, 1993.

[194] S. A. Beshyah, P. Kyd, E. Thomas, A. Fairney, and D. G. Johnston, "The effects of prolonged growth hormone replacement on bone metabolism and bone mineral density in hypopituitary adult," Clinical Endocrinology, vol. 42, no. 3, pp. 249-254, 1995.

[195] J. M. Gómez, N. Gómez, J. Fiter, and J. Soler, "Effects of long-term treatment with $\mathrm{GH}$ in the bone mineral density of adults with hypopituitarism and GH deficiency and after discontinuation of GH replacement," Hormone and Metabolic Research, vol. 32, no. 2, pp. 66-70, 2000.

[196] H. Kotzmann, M. Riedl, P. Bernecker et al., "Effect of longterm growth-hormone substitution therapy on bone mineral density and parameters of bone metabolism in adult patients with growth hormone deficiency," Calcified Tissue International, vol. 62 , no. 1, pp. 40-46, 1998.

[197] J. Johansson, K. Landin, G. Johannsson, L. Tengborn, and B. Bengtsson, "Long-term treatment with growth hormone decreases plasminogen activator inhibitor-1 and tissue plasminogen activator in growth hormone-deficient adults," Thrombosis and Haemostasis, vol. 76, no. 3, pp. 422-428, 1996.

[198] G. Götherström, B. A. Bengtsson, I. Bossæus, G. Johansson, and J. Svensson, "Ten-year GH replacement increase bone mineral density in hypopituitary patients with adult onset GH 
deficiency," European Journal of Endocrinology, vol. 156, no. 1, pp. 55-64, 2007.

[199] M. Elbornsson, G. Götherström, I. Bosæus, B. Bengtsson, G. Johannsson, and J. Svensson, "Fifteen years of GH replacement increases bone mineral density in hypopituitary patients with adult-onset GH deficiency," European Journal of Endocrinology, vol. 166, no. 5, pp. 787-795, 2012.

[200] G. Johannsson, T. Rosén, I. Bosaeus, L. Sjöström, and B. Bengtsson, "Two years of growth hormone $(\mathrm{GH})$ treatment increases bone mineral content and density in hypopituitary patients with adult-onset GH deficiency," Journal of Clinical Endocrinology and Metabolism, vol. 81, no. 8, pp. 2865-2873, 1996.

[201] G. Mazziotti, A. Bianchi, S. Bonadonna et al., "Increased prevalence of radiological spinal deformities in adult patients with GH deficiency: influence of GH replacement therapy," Journal of Bone and Mineral Research, vol. 21, no. 4, pp. 520528, 2006.

[202] M. Barake, A. Klibanski, and N. A. Tritos, "Effects of recombinant human growth hormone therapy on bone mineral density in adults with growth hormone deficiency: a meta-analysis," The Journal of Clinical Endocrinology \& Metabolism, vol. 99, no. 3, pp. 852-860, 2014.

[203] S. R. Cummings and L. J. Melton III, "Epidemiology and outcomes of osteoporotic fractures," The Lancet, vol. 359, no. 9319, pp. 1761-1767, 2002.

[204] A. C. Looker, E. S. Orwoll, C. C. Johnston Jr. et al., "Prevalence of low femoral bone density in older U.S. adults from NHANES III," Journal of Bone and Mineral Research, vol. 12, no. 11, pp. 1761-1768, 1997.

[205] Z. A. Cole, E. M. Dennison, and C. Cooper, "Osteoporosis epidemiology update," Current Rheumatology Reports, vol. 10, no. 2, pp. 92-96, 2008.

[206] L. G. Raisz, "Pathogenesis of osteoporosis: concepts, conflicts, and prospects," Journal of Clinical Investigation, vol. 115, no. 12, pp. 3318-3325, 2005.

[207] S. Khosla and B. L. Riggs, "Pathophysiology of age-related bone loss and osteoporosis," Endocrinology and Metabolism Clinics of North America, vol. 34, no. 4, pp. 1015-1030, 2005.

[208] S. Perrini, L. Laviola, M. C. Carreira, A. Cignarelli, A. Natalicchio, and F. Giorgino, "The GH/IGF1 axis and signaling pathways in the muscle and bone: mechanisms underlying agerelated skeletal muscle wasting and osteoporosis," Journal of Endocrinology, vol. 205, no. 3, pp. 201-210, 2010.

[209] E. Seeman, "Pathogenesis of bone fragility in women and men," The Lancet, vol. 359, no. 9320, pp. 1841-1850, 2002.

[210] S. Khosla, L. J. Melton III, and B. L. Riggs, “The unitary model for estrogen deficiency and the pathogenesis of osteoporosis: is a revision needed?" Journal of Bone and Mineral Research, vol. 26, no. 3, pp. 441-451, 2011.

[211] P. Garnero, E. Sornay-Rendu, M. C. Chapuy, and P. D. Delmas, "Increased bone turnover in late postmenopausal women is a major determinant of osteoporosis," Journal of Bone and Mineral Research, vol. 11, no. 3, pp. 337-349, 1996.

[212] M. T. Hannan, D. T. Felson, B. Dawson-Hughes et al., "Risk factors for longitudinal bone loss in elderly men and women: the Framingham Osteoporosis Study," Journal of Bone and Mineral Research, vol. 15, no. 4, pp. 710-720, 2000.

[213] C. Cooper, G. Campion, and L. J. Melton III, "Hip fractures in the elderly: a world-wide projection," Osteoporosis International, vol. 2, no. 6, pp. 285-289, 1992.
[214] H. Burger, P. L. A. van Daele, K. Grashuis et al., "Vertebral deformities and functional impairment in men and women," Journal of Bone and Mineral Research, vol. 12, no. 1, pp. 152-157, 1997.

[215] M. Thomas-John, M. B. Codd, S. Manne, N. B. Watts, and A. Mongey, "Risk factors for the development of osteoporosis and osteoporotic fractures among older men," Journal of Rheumatology, vol. 36, no. 9, pp. 1947-1952, 2009.

[216] S. C. Manolagas, "From estrogen-centric to aging and oxidative stress: a revised perspective of the pathogenesis of osteoporosis," Endocrine Reviews, vol. 31, no. 3, pp. 266-300, 2010.

[217] G. A. Ledger, M. F. Burritt, P. C. Kao, W. M. O’Fallon, B. L. Riggs, and S. Khosla, "Role of parathyroid hormone in mediating nocturnal and age-related increases in bone resorption," Journal of Clinical Endocrinology \& Metabolism, vol. 80, no. 11, pp. 33043310, 1995.

[218] V. Nicolas, A. Prewett, P. Bettica et al., "Age-related decreases in insulin-like growth factor-I and transforming growth factor- $\beta$ in femoral cortical bone from both men and women: implications for bone loss with aging," Journal of Clinical Endocrinology and Metabolism, vol. 78, no. 5, pp. 1011-1016, 1994.

[219] S. Ljunghall, A. G. Johansson, P. Burman, O. Kampe, E. Lindh, and F. A. Karlsson, "Low plasma levels of insulin-like growth factor 1 (IGF-1) in male patients with idiopathic osteoporosis," Journal of Internal Medicine, vol. 232, no. 1, pp. 59-64, 1992.

[220] L. Maïmoun, O. Coste, F. Galtier et al., "Bone mineral density acquisition in peripubertal female rhythmic gymnasts is directly associated with plasma IGF1/IGF-binding protein 3 ratio," European Journal of Endocrinology, vol. 163, no. 1, pp. 157$164,2010$.

[221] S. Boonen, E. Lesaffre, J. Dequeker et al., "Relationship between baseline insulin-like growth factor-I (IGF-I) and femoral bone density in women aged over 70 years: potential implications for the prevention of age-related bone loss," Journal of the American Geriatrics Society, vol. 44, no. 11, pp. 1301-1306, 1996.

[222] C. Wuster, W. F. Blum, S. Schlemilch, M. B. Ranke, and R. Ziegler, "Decreased serum levels of insulin-like growth factors and IGF binding protein 3 in osteoporosis," Journal of Internal Medicine, vol. 234, no. 3, pp. 249-255, 1993.

[223] S. Khosla, E. J. Atkinson, L. J. Melton III, and B. L. Riggs, "Effects of age and estrogen status on serum parathyroid hormone levels and biochemical markers of bone turnover in women: a population-based study," The Journal of Clinical Endocrinology \& Metabolism, vol. 82, no. 5, pp. 1522-1527, 1997.

[224] J. P. T. Span, G. F. F. M. Pieters, C. G. J. Sweep, A. R. M. M. Hermus, and A. G. H. Smals, "Gender difference in insulin-like growth factor I response to growth hormone (GH) treatment in GH-deficient adults: Role of sex hormone replacement," Journal of Clinical Endocrinology and Metabolism, vol. 85, no. 3, pp. 1121$1125,2000$.

[225] B. C. Nindl, M. Santtila, J. Vaara, K. Hakkinen, and H. Kyrolainen, "Circulating IGF-I is associated with fitness and health outcomes in a population of 846 young healthy men," Growth Hormone and IGF Research, vol. 21, no. 3, pp. 124-128, 2011.

[226] W. J. Kraemer, C. Dunn-Lewis, B. A. Comstock, G. A. Thomas, J. E. Clark, and B. C. Nindl, "Growth hormone, exercise, and athletic performance: a continued evolution of complexity," Current Sports Medicine Reports, vol. 9, no. 4, pp. 242-252, 2010.

[227] S. M. Gregory, B. A. Spiering, J. A. Alemany et al., "Exerciseinduced insulin-like growth factor I system concentrations after training in women," Medicine and Science in Sports and Exercise, vol. 45, no. 3, pp. 420-428, 2013. 
[228] P. C. Henning, D. E. Scofield, K. R. Rarick et al., "Effects of acute caloric restriction compared to caloric balance on the temporal response of the IGF-I system," Metabolism: Clinical and Experimental, vol. 62, no. 2, pp. 179-187, 2013.

[229] T. Chevalley, P. Hoffmeyer, J. Bonjour, and R. Rizzoli, "Early serum IGF-I response to oral protein supplements in elderly women with a recent hip fracture," Clinical Nutrition, vol. 29, no. 1, pp. 78-83, 2010.

[230] A. L. Darling, D. J. Millward, D. J. Torgerson, C. E. Hewitt, and S. A. Lanham-New, "Dietary protein and bone health: a systematic review and meta-analysis," The American Journal of Clinical Nutrition, vol. 90, no. 6, pp. 1674-1692, 2009.

[231] C. Franceschi, M. Bonafè, S. Valensin et al., "Inflamm-aging. An evolutionary perspective on immunosenescence," Annals of the New York Academy of Sciences, vol. 908, pp. 244-254, 2000.

[232] M. S. Nanes, “Tumor necrosis factor-alpha: Molecular and cellular mechanisms in skeletal pathology," Gene, vol. 321, no. 1-2, pp. 1-15, 2003.

[233] E. C. Wahl, J. Aronson, L. Liu et al., "Restoration of regenerative osteoblastogenesis in aged mice: modulation of TNF," Journal of Bone and Mineral Research, vol. 25, no. 1, pp. 114-123, 2010.

[234] S. Boonen, E. Lesaffre, J. Aerssens, W. Pelemans, J. Dequeker, and R. Bouillon, "Deficiency of the growth hormone-insulinlike growth factor-1 axis potentially involved in age-related alterations in body composition," Gerontology, vol. 42, no. 6, pp. 330-338, 1996.

[235] J. D. Veldhuis and C. Y. Bowers, "Human GH pulsatility: an ensemble property regulated by age and gender," Journal of Endocrinological Investigation, vol. 26, no. 9, pp. 799-813, 2003.

[236] C. A. Benbassat, K. C. Maki, and T. G. Unterman, "Circulating levels of insulin-like growth factor (IGF) binding protein- 1 and -3 in aging men: relationships to insulin, glucose, IGF, and dehydroepiandrosterone sulfate levels and anthropometric measures," Journal of Clinical Endocrinology and Metabolism, vol. 82, no. 5, pp. 1484-1491, 1997.

[237] M. Nasu, T. Sugimoto, M. Chihara, M. Hiraumi, F. Kurimoto, and K. Chihara, "Effect of natural menopause on serum levels of IGF-I and IGF-binding proteins: Relationship with bone mineral density and lipid metabolism in perimenopausal women," European Journal of Endocrinology, vol. 136, no. 6, pp. 608-616, 1997.

[238] E. Romagnoli, S. Minisola, V. Carnevale et al., "Circulating levels of insulin-like growth factor binding protein 3 (IGFBP3 ) and insulin-like growth factor I (IGF-I) in perimenopausal women," Osteoporosis International, vol. 4, no. 6, pp. 305-308, 1994.

[239] M. Muñoz-Torres, P. Mezquita-Raya, F. Lopez-Rodriguez, E. Torres-Vela, J. de Dios Luna, and F. Escobar-Jimenez, "The contribution of IGF-I to skeletal integrity in postmenopausal women," Clinical Endocrinology, vol. 55, no. 6, pp. 759-766, 2001.

[240] P. Gillberg, H. Olofsson, H. Mallmin, W. F. Blum, S. Ljunghall, and A. G. Nilsson, "Bone mineral density in femoral neck is positively correlated to circulating insulin-like growth factor (IGF)-I and IGF-binding protein (IGFBP)-3 in Swedish men," Calcified Tissue International, vol. 70, no. 1, pp. 22-29, 2002.

[241] H. P. Kruse and F. Kuhlencordt, "On an attempt to treat primary and secondary osteoporosis with human growth hormone," Hormone and Metabolic Research, vol. 7, no. 6, pp. 488-491, 1975.

[242] K. Brixen, H. K. Nielsen, L. Mosekilde, and A. Flyvbjerg, "A short course of recombinant human growth hormone treatment stimulates osteoblasts and activates bone remodeling in normal human volunteers," Journal of Bone and Mineral Research, vol. 5, no. 6, pp. 609-618, 1990.

[243] D. Rudman, A. G. Feller, H. S. Nagraj et al., "Effects of human growth hormone in men over 60 years old," The New England Journal of Medicine, vol. 323, no. 1, pp. 1-6, 1990.

[244] L. Holloway, G. Butterfield, R. L. Hintz, N. Gesundheit, and R. Marcus, "Effects of recombinant human growth hormone on metabolic indices, body composition, and bone turnover in healthy elderly women," Journal of Clinical Endocrinology and Metabolism, vol. 79, no. 2, pp. 470-479, 1994.

[245] T. Bianda, M. A. Hussain, Y. Glatz, R. Bouillon, E. R. Froesch, and C. Schmid, "Effects of short-term insulin-like growth factor-I or growth hormone treatment on bone turnover, renal phosphate reabsorption and 1,25 dihydroxyvitamin D3 production in healthy man," Journal of Internal Medicine, vol. 241, no. 2, pp. 143-150, 1997.

[246] B. Clemmesen, K. Overgaard, B. Riis, and C. Christiansen, "Human growth hormone and growth hormone releasing hormone: a double-masked, placebo-controlled study of their effects on bone metabolism in elderly women," Osteoporosis International, vol. 3, no. 6, pp. 330-336, 1993.

[247] M. Kassem, K. Brixen, W. Blum, L. Mosekilde, and E. F. Eriksen, "No evidence for reduced spontaneous or growth-hormonestimulated serum levels of insulin-like growth factor (IGF)I, IGF-II or IGF binding protein 3 in women with spinal osteoporosis," European Journal of Endocrinology, vol. 131, no. 2, pp. $150-155,1994$.

[248] R. J. Erdtsieck, H. A. P. Pols, N. K. Valk et al., "Treatment of post-menopausal osteoporosis with a combination of growth hormone and pamidronate: a placebo controlled trial," Clinical Endocrinology, vol. 43, no. 5, pp. 557-565, 1995.

[249] L. Holloway, L. Kohlmeier, K. Kent, and R. Marcus, "Skeletal effects of cyclic recombinant human growth hormone and salmon calcitonin in osteopenic postmenopausal women," Journal of Clinical Endocrinology and Metabolism, vol. 82, no. 4, pp. 1111-1117, 1997.

[250] M. Kassem, K. Brixen, L. Mosekilde, W. F. Blum, and A. Flyvbjerg, "Effects of growth hormone treatment on serum levels of insulin-like growth factors (IGFs) and IGF binding proteins 1-4 in postmenopausal women," Clinical Endocrinology, vol. 49, no. 6, pp. 747-756, 1998.

[251] T. Sugimoto, D. Nakaoka, M. Nasu, M. Kanzawa, T. Sugishita, and K. Chihara, "Effect of recombinant human growth hormone in elderly osteoporotic women," Clinical Endocrinology, vol. 51, no. 6, pp. 715-724, 1999.

[252] M. Sääf, A. Hilding, M. Thorén, S. Troell, and K. Hall, “Growth hormone treatment of osteoporotic postmenopausal womena one-year placebo-controlled study," European Journal of Endocrinology, vol. 140, no. 5, pp. 390-399, 1999.

[253] T. Sugimoto, H. Kaji, D. Nakaoka et al., "Effect of low-dose of recombinant human growth hormone on bone metabolism in elderly women with osteoporosis," European Journal of Endocrinology, vol. 147, no. 3, pp. 339-348, 2002.

[254] P. Gillberg, H. Mallmin, M. Petrén-Mallmin, S. Ljunghall, and A. G. Nilsson, "Two years of treatment with recombinant human growth hormone increases bone mineral density in men with idiopathic osteoporosis," Journal of Clinical Endocrinology \& Metabolism, vol. 87, no. 11, pp. 4900-4906, 2002.

[255] K. Landin-Wilhelmsen, A. Nilsson, I. Bosaeus, and B. Bengtsson, "Growth hormone increases bone mineral content in postmenopausal osteoporosis: a randomized placebo-controlled 
trial," Journal of Bone and Mineral Research, vol. 18, no. 3, pp. 393-405, 2003.

[256] F. Joseph, A. M. Ahmad, M. Ul-Haq et al., "Effects of growth hormone administration on bone mineral metabolism, PTH sensitivity and PTH secretory rhythm in postmenopausal women with established osteoporosis," Journal of Bone and Mineral Research, vol. 23, no. 5, pp. 721-729, 2008.

[257] A. G. Johansson, E. Lindh, W. F. Blum, G. Kollerup, O. H. Sørensen, and S. Ljunghall, "Effects of growth hormone and insulin-like growth factor I in men with idiopathic osteoporosis," Journal of Clinical Endocrinology and Metabolism, vol. 81, no. 1, pp. 44-48, 1996.

[258] H. D. White, A. M. Ahmad, B. H. Durham et al., "Growth hormone replacement is important for the restoration of parathyroid hormone sensitivity and improvement in bone metabolism in older adult growth hormone-deficient patients," Journal of Clinical Endocrinology and Metabolism, vol. 90, no. 6, pp. 3371-3380, 2005.

[259] K. K. Y. Ho and A. J. Weissberger, "Impact of short-term estrogen administration on growth hormone secretion and action: distinct route-dependent effects on connective and bone tissue metabolism," Journal of Bone and Mineral Research, vol. 7, no. 7, pp. 821-827, 1992.

[260] R. Marcus, G. Butterfield, L. Holloway et al., "Effects of short term administration of recombinant human growth hormone to elderly people," Journal of Clinical Endocrinology and Metabolism, vol. 70, no. 2, pp. 519-527, 1990.

[261] T. L. Bianda, "Effects of growth hormone (GH) and insulinlike growth factor-I on serum leptin in GH-deficient adults," Diabetologia, vol. 40, no. 3, pp. 363-364, 1997.

[262] A. G. Johansson, E. Lindh, and S. Ljunghall, "Insulin-like growth factor I stimulates bone turnover in osteoporosis," The Lancet, vol. 339, no. 8809, article 1619, 1992.

[263] P. R. Ebeling, J. D. Jones, W. M. O'Fallon, C. H. Janes, and B. L. Riggs, "Short-term effects of recombinant human insulin-like growth factor I on bone turnover in normal women," Journal of Clinical Endocrinology and Metabolism, vol. 77, no. 5, pp. 13841387, 1993.

[264] C. D. Rubin, B. Reed, K. Sakhaee, and C. Y. C. Pak, "Treating a patient with the Werner syndrome and osteoporosis using recombinant human insulin-like growth factor," Annals of Internal Medicine, vol. 121, no. 9, pp. 665-668, 1994.

[265] S. K. Grinspoon, H. B. A. Baum, S. Peterson, and A. Klibanski, "Effects of rhIGF-I administration on bone turnover during short-term fasting," Journal of Clinical Investigation, vol. 96, no. 2, pp. 900-906, 1995.

[266] L. J. Ghiron, J. L. Thompson, L. Holloway et al., "Effects of recombinant insulin-like growth factor-I and growth hormone on bone turnover in elderly women," Journal of Bone and Mineral Research, vol. 10, no. 12, pp. 1844-1852, 1995.

[267] S. Grinspoon, H. Baum, K. Lee, E. Anderson, D. Herzog, and A. Klibanski, "Effects of short-term recombinant human insulin-like growth factor I administration on bone turnover in osteopenic women with anorexia nervosa," Journal of Clinical Endocrinology and Metabolism, vol. 81, no. 11, pp. 3864-3870, 1996.

[268] N. Mauras, S. Q. Doi, and J. R. Shapiro, "Recombinant human insulin-like growth factor I, recombinant human growth hormone, and sex steroids: effects on markers of bone turnover in humans," Journal of Clinical Endocrinology and Metabolism, vol. 81, no. 6, pp. 2222-2226, 1996.
[269] A. L. Friedlander, G. E. Butterfield, S. Moynihan et al., "One year of insulin-like growth factor I treatment does not affect bone density, body composition, or psychological measures in postmenopausal women," The Journal of Clinical Endocrinology \& Metabolism, vol. 86, no. 4, pp. 1496-1503, 2001.

[270] S. Boonen, C. Rosen, R. Bouillon et al., "Musculoskeletal effects of the recombinant human IGF-I/IGF binding protein3 complex in osteoporotic patients with proximal femoral fracture: a double-blind, placebo-controlled pilot study," Journal of Clinical Endocrinology and Metabolism, vol. 87, no. 4, pp. 1593-1599, 2002.

[271] S. Grinspoon, L. Thomas, K. Miller, D. Herzog, and A. Klibanski, "Effects of recombinant human IGF-I and oral contraceptive administration on bone density in anorexia nervosa," Journal of Clinical Endocrinology and Metabolism, vol. 87, no. 6, pp. 2883-2891, 2002.

[272] S. Grinspoon, K. Miller, D. Herzog, D. Clemmons, and A. Klibanski, "Effects of recombinant human insulin-like growth factor (IGF)-I and estrogen administration on IGF-I, IGF binding protein (IGFBP)-2, and IGFBP-3 in anorexia nervosa: a randomized-controlled study," Journal of Clinical Endocrinology and Metabolism, vol. 88, no. 3, pp. 1142-1149, 2003.

[273] M. Misra, J. McGrane, K. K. Miller et al., "Effects of rhIGF1 administration on surrogate markers of bone turnover in adolescents with anorexia nervosa," Bone, vol. 45, no. 3, pp. 493498, 2009.

[274] A. J. van der Lely, S. W. Lamberts, K. W. Jauch et al., "Use of human GH in elderly patients with accidental hip fracture," European Journal of Endocrinology, vol. 143, no. 5, pp. 585-592, 2000.

[275] A.-L. Yeo, D. Levy, F. C. Martin et al., "Frailty and the biochemical effects of recombinant human growth hormone in women after surgery for hip fracture," Growth Hormone and IGF Research, vol. 13, no. 6, pp. 361-370, 2003.

[276] A. J. Weissberger, A. D. Anastasiadis, I. Sturgess, F. C. Martin, M. A. Smith, and P. H. Sönksen, "Recombinant human growth hormone treatment in elderly patients undergoing elective total hip replacement," Clinical Endocrinology, vol. 58, no. 1, pp. 99$107,2003$.

[277] M. Hedström, M. Sääf, E. Brosjö et al., "Positive effects of shortterm growth hormone treatment on lean body mass and BMC after a hip fracture: a double-blind placebo-controlled pilot study in 20 patients," Acta Orthopaedica Scandinavica, vol. 75, no. 4, pp. 394-401, 2004.

[278] M. Raschke, M. Højby Rasmussen, S. Govender, D. Segal, M. Suntum, and J. S. Christiansen, "Effects of growth hormone in patients with tibial fracture: a randomised, doubleblind, placebo-controlled clinical trial," European Journal of Endocrinology, vol. 156, no. 3, pp. 341-351, 2007.

[279] T. Krusenstjerna-Hafstrøm, M. H. Rasmussen, M. Raschke, S. Govender, J. Madsen, and J. S. Christiansen, "Biochemical markers of bone turnover in tibia fracture patients randomly assigned to growth hormone $(\mathrm{GH})$ or placebo injections. Implications for detection of GH abuse," Growth Hormone and IGF Research, vol. 21, no. 6, pp. 331-335, 2011.

[280] A. G. Johansson, E. Lindh, G. Kollerup, and S. Ljunghal, "Dosedependent of IGF-1 on the metabolism of collagen type I in male osteoporosis," Journal of Bone and Mineral Research, vol. 10, article S393, 1995.

[281] A. V. Papavasiliou, "Histological and biological changes in the epiphyseal plate during fracture healing," Journal of Orthopaedic Science, vol. 7, no. 1, pp. 91-96, 2002. 
[282] M. A. Mont, L. C. Jones, T. A. Einhorn, D. S. Hungerford, and A. H. Reddi, "Osteonecrosis of the femoral head: potential treatment with growth and differentiation factors," Clinical Orthopaedics and Related Research, no. 355, pp. S314-S335, 1998.

[283] S. N. Lissenberg-Thunnissen, D. J. J. de Gorter, C. F. M. Sier, and I. B. Schipper, "Use and efficacy of bone morphogenetic proteins in fracture healing," International Orthopaedics, vol. 35, no. 9, pp. 1271-1280, 2011.

[284] H. Bail, M. J. Raschke, S. F. Kolbeck, A. Weiler, P. M. Haahr, and N. P. Haas, "Recombinant growth hormone increasus callus maturation time in distraction osteogenesis-a histomorphometric study," Langenbecks Archiv für Chirurgie, vol. 115, supplement I, pp. 675-680, 1998.

[285] S. D. Cook, G. C. Baffes, M. W. Wolfe, T. K. Sampath, D. C. Rueger, and T. S. Whitecloud III, "The effect of recombinant human osteogenic protein-1 on healing of large segmental bone defects," Journal of Bone and Joint Surgery A, vol. 76, no. 6, pp. 827-838, 1994.

[286] H. Kawaguchi, T. Kurokawa, K. Hanada et al., "Stimulation of fracture repair by recombinant human basic fibroblast growth factor in normal and streptozotocin-diabetic rats," Endocrinology, vol. 135, no. 2, pp. 774-781, 1994.

[287] H. M. Nielsen, B. Bak, P. H. Jorgensen, and T. T. Andreassen, "Growth hormone promotes healing of tibial fractures in the rat," Acta Orthopaedica Scandinavica, vol. 62, no. 3, pp. 244-247, 1991.

[288] T. J. Nash, C. R. Howlett, C. Martin, J. Steele, K. A. Johnson, and D. J. Hicklin, "Effect of platelet-derived growth factor on tibial osteotomies in rabbits," Bone, vol. 15, no. 2, pp. 203-208, 1994.

[289] R. F. Spencer, "The effect of head injury on fracture healing. A quantitative assessment," Journal of Bone and Joint Surgery B, vol. 69 , no. 4, pp. 525-528, 1987.

[290] S. M. Bidner, I. M. Rubins, J. V. Desjardins, D. J. Zukor, and D. Goltzman, "Evidence for a humoral mechanism for enhanced osteogenesis after head injury," Journal of Bone and Joint Surgery, vol. 72, no. 8, pp. 1144-1149, 1990.

[291] D. Gazit, M. Karmish, L. Holzman, and I. Bab, "Regenerating marrow induces systemic increase in osteo- and chondrogenesis," Endocrinology, vol. 126, no. 5, pp. 2607-2613, 1990.

[292] S. Weiss, P. Henle, M. Bidlingmaier, A. Moghaddam, P. Kasten, and G. Zimmermann, "Systemic response of the GH/IGF-I axis in timely versus delayed fracture healing," Growth Hormone and IGF Research, vol. 18, no. 3, pp. 205-212, 2008.

[293] M. di Monaco, F. Vallero, R. Di Monaco, R. Tappero, and A. Cavanna, "Serum levels of insulin-like growth factor-I are positively associated with functional outcome after hip fracture in elderly women," The American Journal of Physical Medicine and Rehabilitation, vol. 88, no. 2, pp. 119-125, 2009.

[294] G. Johannsson and C. Ohlsson, "Growth hormone therapy and fracture risk in the growth hormone-deficient adult," Bailliere's Clinical Endocrinology and Metabolism, vol. 12, no. 2, pp. 233250, 1998.

[295] S. Yang, L. Cao, S. Cai, J. Yuan, and J. Wang, "A systematic review of growth hormone for hip fractures," Growth Hormone and IGF Research, vol. 22, no. 3-4, pp. 97-101, 2012.

[296] B. R. Bistrian, J. Schwartz, and N. W. Istfan, "Cytokines, muscle proteolysis, and the catabolic response to infection and inflammation," Proceedings of the Society for Experimental Biology and Medicine, vol. 200, no. 2, pp. 220-223, 1992.

[297] D. W. Wilmore, "Catabolic illness: Strategies for enhancing recovery," The New England Journal of Medicine, vol. 325, no. 10, pp. 695-702, 1991.
[298] R. N. Cooney and M. Shumate, "The inhibitory effects of interleukin-1 on growth hormone action during catabolic illness," Vitamins \& Hormones, vol. 74, pp. 317-340, 2006.

[299] S. von Laue and R. J. M. Ross, "Inflammatory cytokines and acquired growth hormone resistance," Growth Hormone and IGF Research, vol. 10, S9, p. S14, 2000.

[300] G. Yumet, M. L. Shumate, D. P. Bryant, C. H. Lang, and R. $\mathrm{N}$. Cooney, "Hepatic growth hormone resistance during sepsis is associated with increased suppressors of cytokine signaling expression and impaired growth hormone signaling," Critical Care Medicine, vol. 34, no. 5, pp. 1420-1427, 2006.

[301] G. Yumet, M. L. Shumate, P. Bryant, C. Lin, C. H. Lang, and R. N. Cooney, "Tumor necrosis factor mediates hepatic growth hormone resistance during sepsis," American Journal of Physiology: Endocrinology and Metabolism, vol. 283, no. 3, pp. E472E481, 2002.

[302] T. A. Ahmed, M. D. Buzzelli, C. H. Lang et al., "Interleukin-6 inhibits growth hormone-mediated gene expression in hepatocytes," American Journal of Physiolog: Gastrointestinal and Liver Physiology, vol. 292, no. 6, pp. G1793-G1803, 2007.

[303] A. A. Samani, S. Yakar, D. LeRoith, and P. Brodt, "The role of the IGF system in cancer growth and metastasis: overview and recent insights," Endocrine Reviews, vol. 28, no. 1, pp. 20-47, 2007.

[304] E. Seccareccia and P. Brodt, "The role of the insulin-like growth factor-I receptor in malignancy: an update," Growth Hormone \& IGF Research, vol. 22, no. 6, pp. 193-199, 2012.

[305] A. Deodati, B. B. Ferroli, and S. Cianfarani, "Association between growth hormone therapy and mortality, cancer and cardiovascular risk: systematic review and meta-analysis," Growth Hormone and IGF Research, 2014.

[306] J. C. Carel, E. Ecosse, F. Landier et al., "Long-term mortality after recombinant growth hormone treatment for isolated growth hormone deficiency or childhood short stature: preliminary report of the French SAGhE study," Journal of Clinical Endocrinology and Metabolism, vol. 97, no. 2, pp. 416-425, 2012.

[307] L. Sävendahl, M. Maes, K. Albertsson-Wikland et al., "Longterm mortality and causes of death in isolated GHD, ISS, and SGA patients treated with recombinant growth hormone during childhood in Belgium, The Netherlands, and Sweden: Preliminary report of 3 countries participating in the EU SAGhE study," Journal of Clinical Endocrinology and Metabolism, vol. 97, no. 2, pp. E213-E217, 2012.

[308] S. Pekic and V. Popovic, "GH therapy and cancer risk in hypopituitarism: what we know from human studies," European Journal of Endocrinology, vol. 169, no. 5, pp. R89-R97, 2013.

[309] B. Ergun-Longmire, A. C. Mertens, P. Mitby et al., "Growth hormone treatment and risk of second neoplasms in the childhood cancer survivor," Journal of Clinical Endocrinology and Metabolism, vol. 91, no. 9, pp. 3494-3498, 2006.

[310] V. Popovic, A. F. Mattsson, R. C. Gaillard, P. Wilton, M. Kołtowska-Häggström, and M. B. Ranke, "Serum insulin-like growth factor I (IGF-I), IGF-binding proteins 2 and 3, and the risk for development of malignancies in adults with growth hormone $(\mathrm{GH})$ deficiency treated with $\mathrm{GH}$ : data from KIMS (Pfizer International Metabolic Database)," Journal of Clinical Endocrinology and Metabolism, vol. 95, no. 9, pp. 4449-4454, 2010.

[311] H. Xiang, Y. Wang, and S. Nie, "Meta-analysis of the association between insulin-like growth factor binding protein 3 genetic polymorphisms and colorectal cancer susceptibility," PLoS ONE, vol. 8, no. 3, Article ID e59665, 2013. 
[312] K. Chihara, Y. Kato, H. Kohno et al., "Safety and efficacy of growth hormone $(\mathrm{GH})$ during extended treatment of adult Japanese patients with GH deficiency (GHD)," Growth Hormone and IGF Research, vol. 18, no. 4, pp. 307-317, 2008.

[313] N. Mauras, A. D. Rogol, M. W. Haymond, and J. D. Veldhuis, "Sex steroids, growth hormone, insulin-like growth factor-1: neuroendocrine and metabolic regulation in puberty," Hormone Research, vol. 45, no. 1-2, pp. 74-80, 1996.

[314] S. Khosla, L. J. Melton, and B. L. Riggs, "Estrogens and bone health in men," Calcified Tissue International, vol. 69, no. 4, pp. 189-192, 2001. 


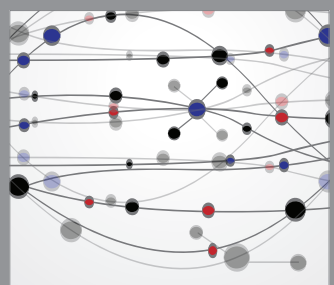

The Scientific World Journal
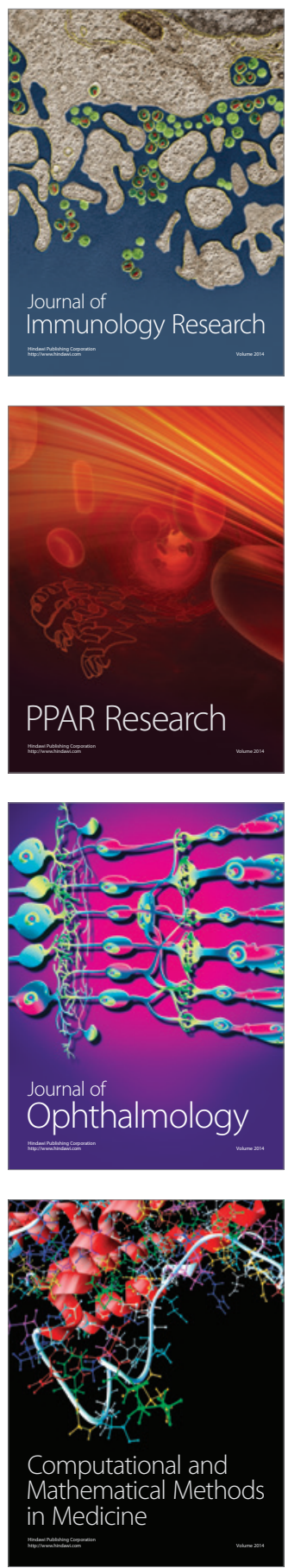

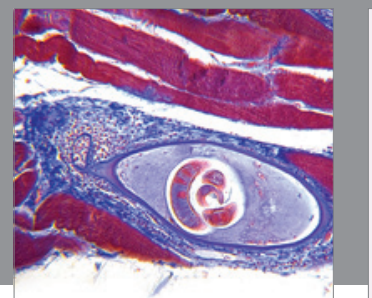

Gastroenterology

Research and Practice
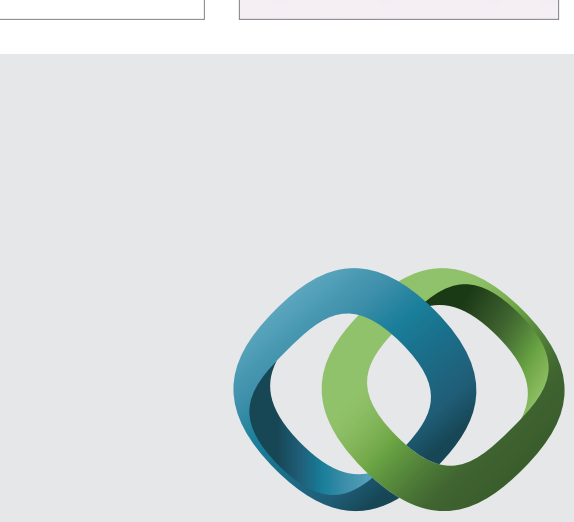

\section{Hindawi}

Submit your manuscripts at

http://www.hindawi.com
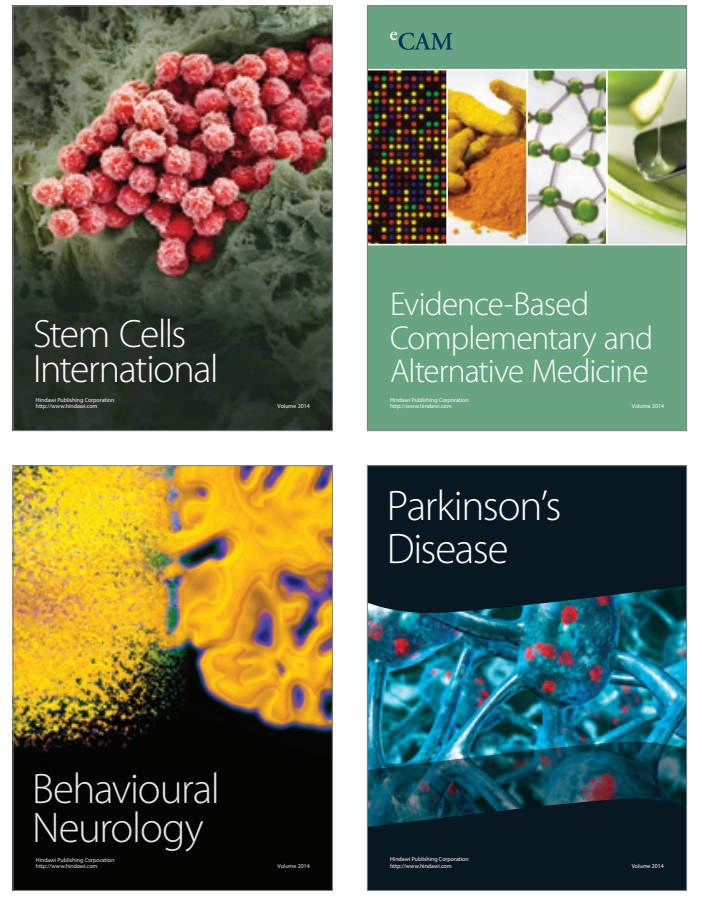
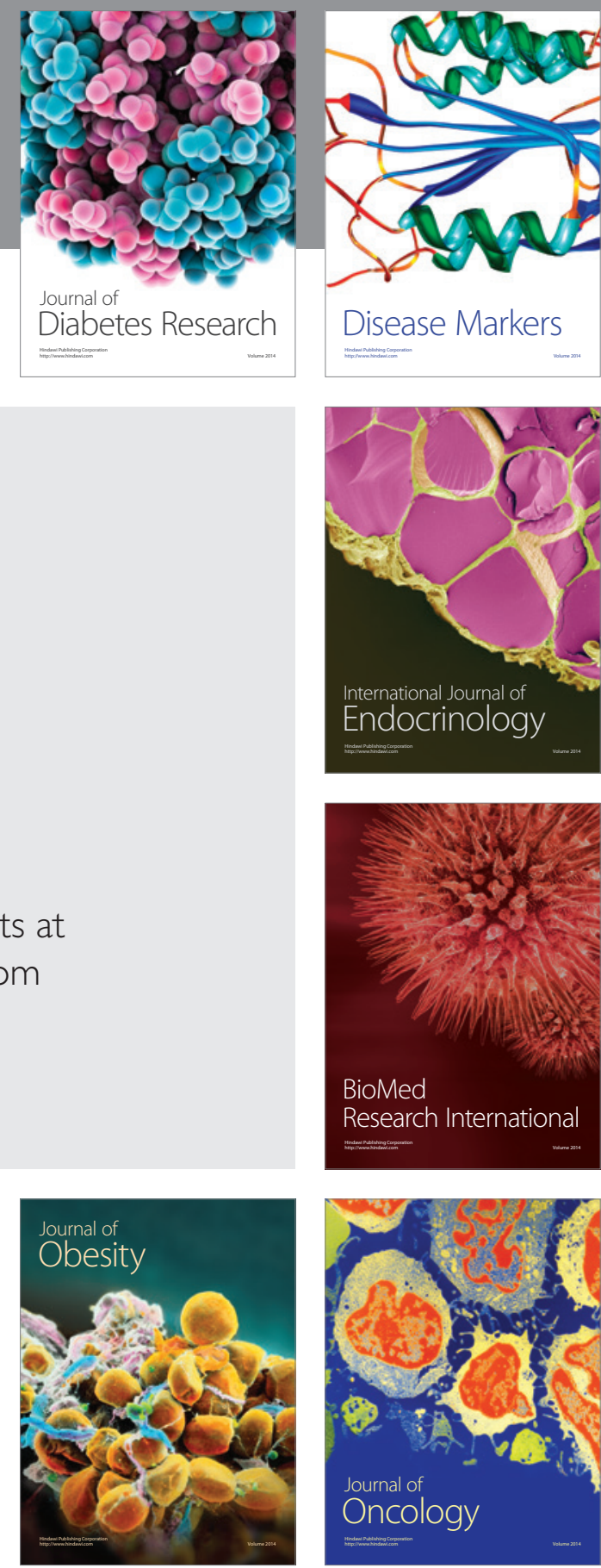

Disease Markers
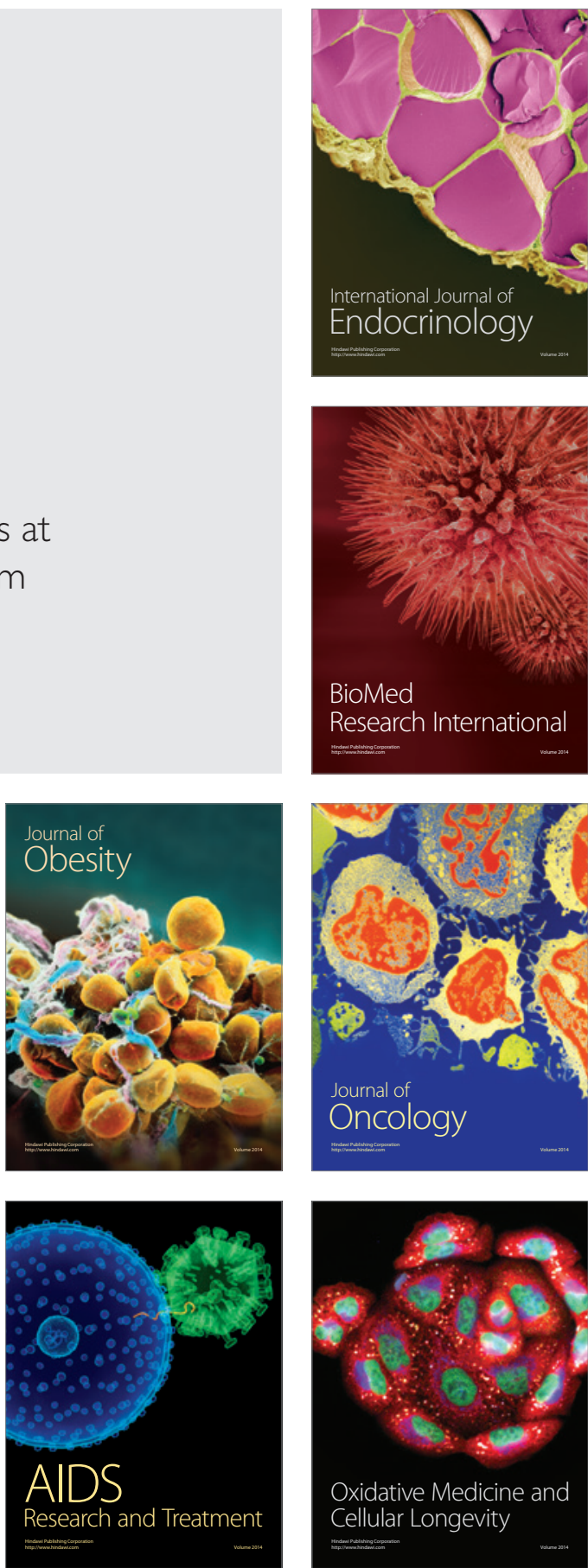